\title{
Removal of Iron Fillings from Corn Flour: Recipe for Sustainable Development
}

\author{
Tarlutu Ibrahim ${ }^{1}$, Abdul-Mumin Abdulai ${ }^{2,3}$, Abdul-Rauf Ibrahim ${ }^{1,4,}$, , Sulemana Yahaya ${ }^{1}$, \\ Alhassan Fadila ${ }^{1}$, Alhassan Yakubu ${ }^{1}$ \\ ${ }^{1}$ Faculty of Engineering, Mechanical Engineering Department, Tamale Technical University, Tamale, Ghana \\ ${ }^{2}$ Faculty of Agriculture, Department of Agribusiness, Tamale Technical University, Tamale, Ghana \\ ${ }^{3}$ International Programmes and Institutional Linkages Directorate, Tamale Technical University, Tamale, Ghana \\ ${ }^{4}$ Institute of Agricultural and Environmental Research, Tamale Technical University, Tamale, Ghana
}

Email address:

iabdulrauf@tatu.edu.gh (Abdul-Rauf I.)

${ }^{*}$ Corresponding author

\section{To cite this article:}

Tarlutu Ibrahim, Abdul-Mumin Abdulai, Abdul-Rauf Ibrahim, Sulemana Yahaya, Alhassan Fadila, Alhassan Yakubu. Removal of Iron Fillings from Corn Flour: Recipe for Sustainable Development. International Journal of Agricultural Economics.

Vol. 6, No. 5, 2021, pp. 227-243. doi: 10.11648/j.ijae.20210605.14

Received: October 6, 2021; Accepted: October 22, 2021; Published: October 30, 2021

\begin{abstract}
We investigated the accumulation of iron fillings in corn flour in the Tamale Metropolis using a permanent magnet. We also assessed the metal accumulation in food delicacies and the possible metal concentration in consumers. We then categorised the food vendors in the Metropolis into domestic, 'low class' and 'high class' commercial vendors. The results revealed that corn flour milled with new pair of plates is likely to contain 1.5 folds Fe than flour milled with old pair of plates. Furthermore, wet milling is the safer choice for producing corn flour than dry milling due to its low metal concentration $(\mathrm{mg} / \mathrm{g})$. Nonetheless, there was no trace of Fe in the porridge samples from the commercial vendors yet the samples from households had the largest metal accumulation and metal concentration. This indicates that consuming koko prepared at home will lead to more $(\approx 1.20 \mathrm{mg} / \mathrm{g}$ ) metal concentration in the body. Incidentally, there was no metal accumulation and no metal concentration from any of the 'high class' commercial TZ vendors due to sieving, demonstrating that they offer the best choice for TZ consumption. Even so, the worse choice for TZ consumption came from the 'low class' commercial TZ vendors due to lack of sieving. As such, the worst meal preference is to eat 3-square (breakfast, lunch and supper) meals of banku prepared at home. Yet, the best meal preferences are: either eat 3-square meals of TZ from 'high class' commercial TZ vendors; or take 3square meals of porridge (koko) from 'high class' commercial porridge vendors; or eat 3-square meals combination of TZ and porridge (Koko) from the 'high class' commercial vendors. Results of the study will influence responsible 'consumption and production' of food (a Sustainable Development Goal; SDG 12) in order to erase hunger (SDG 2). It will also trigger healthier eating habits (meal preferences) to boost and sustain the health and well-being of individuals (SDG 3).
\end{abstract}

Keywords: Iron Fillings, Corn Flour, Sustainable Development Goal, Permanent Magnet, Tamale Metropolis, Metal Concentration, Metal Accumulation, Metal Debris

\section{Introduction}

Globally, people are identified with the kinds of meals and food delicacies they have. The people of northern Ghana (Northern, North East, Savanna, Upper East and Upper Wet regions) and Tamale (Northern Region) in particular are no exception; they have variety of food delicacies among which 'Sagim' (Tou Zaafi-TZ in Hausa language) is the staple and the most enjoyed. Even though other variety of substitute foods such as 'tuubani', 'yama', 'wassa-wassa', 'kenkey' and 'banku' are eaten occasionally, almost all of the substitute foods are prepared from flour. For instance, the typical Northerner takes porridge (koko) or eats ' $\mathrm{TZ}$ ' as breakfast, 'TZ' or 'kenkey' or 'banku' as lunch and eats ' $\mathrm{TZ}$ ' or 'banku' as supper. Porridge and 'TZ' are prepared from the flour of corn, millet or guinea corn but the use of corn for 
these foods has become dominant. On the other hand, 'kenkey' and 'banku' are prepared from corn flour (Figure 1). Therefore, majority of the food delicacies in the Tamale metropolis come from corn flour. In fact, every Ghanaian enjoys one or more delicacies prepared from corn flour; for example, the Southern Regions of Ghana also enjoy porridge, 'TZ', 'banku' and 'kenkey'. Hence, corn flour is an important and indispensable component of food delicacies in the Tamale Metropolis and in Ghana as a whole.

Corn milling is a major activity in Africa [1], especially in Ghana [2]; over $90 \%$ of Ghanaians enjoy food prepared from corn flour [3-6]. Women are responsible for producing corn flour in Africa. They obtain the maize (corn) and send to the milling centers or shops to be milled into corn flour (Figure 2a) for subsequent use. Milling of corn into flour is achieved by means of a pair of locally manufactured metal grinding plates; a stationary one and a rotatory one (Figure 2b). The locally manufactured grinding plates wear faster [7-9] yet majority of milling operators in Ghana actually prefer and use the local plates. This is attributed to the fact that these plates are not expensive and can be obtained easily [10]. Wear of the grinding plates in service implies that debris of metal particles [11-14] would contaminate the flour which will have dire health implications [10-14] and may lead to death [15] when flour contaminated with iron fillings is consumed.

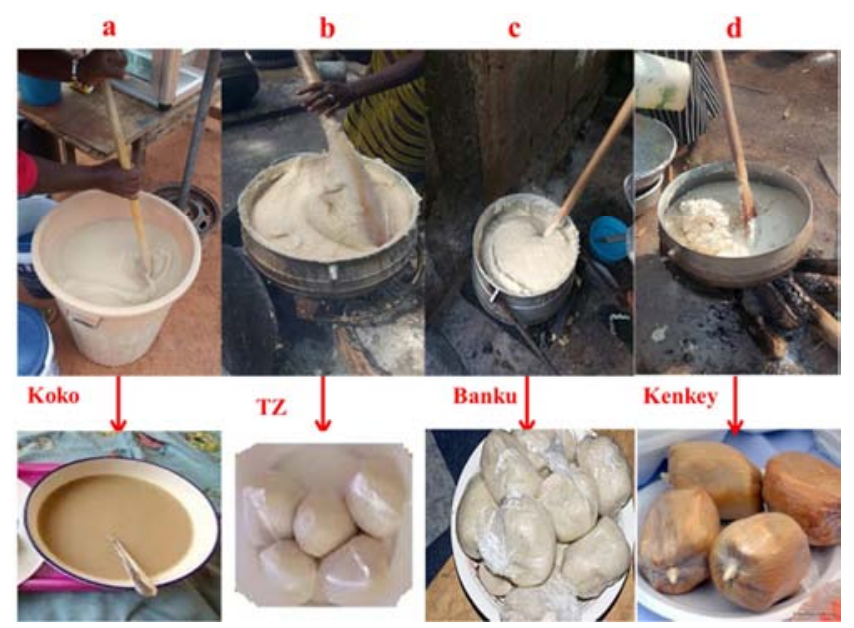

Figure 1. Common food delicacies prepared from corn flour: a) koko (Porridge); b) Sagim (TZ); c) Banku and d) kenkey (Dokono).

\subsection{Production of Iron Fillings}

The grinding mills are designed such that in order to have fine corn flour texture, the operator has to adjust the two (2) grinding plates such that the stationary and the rotatory plates (Figure 2c) come into contact with each other. In this situation (grinding plates contacting each other), iron filings are produced as part of the milled corn flour. This is because when two grooved or burred metallic surfaces (Figure d) made from cast iron especially, get into contact and rub against one another metallic debris will be produced. This metallic debris is what is known as iron filings; production of the iron filings causes the surfaces of the milling plates to get blunt after a period of use and require sharpening. Due to the minute nature of the iron filings and because they are flooded by the corn flour, they usually cannot be seen.
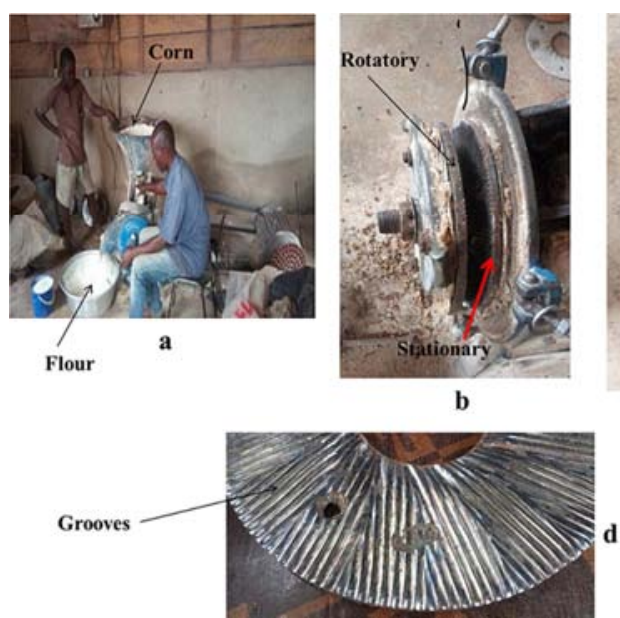

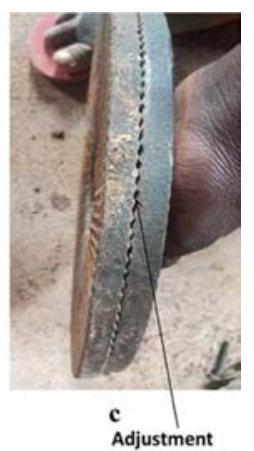

d
Figure 2. Milling corn into corn flour: a) Milling process; b) Stationary and Rotatory grinding plates; c) Adjustment of Rotatory and Stationary plates and d) Grooves on grinding plates.

The causes of wear of the corn mill plates have been investigated in the open literature. Francis (2004) conducted experiments using a magnet to prove the existence of iron fillings in milled food materials and reported that iron fillings from the contact of the milling plates contaminated the milled corn flour [16]. Normanyo et al, (2010) suggested a redesign of grinding mills for the minimisation of iron filing production and showed the existence of iron fillings in flour using a permanent magnet [11]. The authors concluded among others that the cause of the production of the iron filings was the contacting of the grinding plates. Kwofie and Chandler, (2011) studied the quality of locally-manufactured corn mill grinding plates and established the presence of iron fillings in corn flour using an Atomic Absorption Spectrophotometer (AAS). They showed that iron fillings from the contact of the milling plates contaminated the milled corn flour and that the level of contamination increased with the quantity of milled corn [10].

\subsection{Nutritional and Elemental Irons}

Iron is an essential mineral whose key function is to send oxygen round the human body. Its deficiency in the human body can lead to fatigue, dizziness and even death [15]. As such, the importance of consumption of iron and effects of its absence from the human body has long been reported $[11,10$, $17,18]$. In our opinion, the presence of iron in the human body can be grouped into two (2) categories; nutritional and elemental irons. As a nutrient, iron $(\mathrm{Fe})$ is very vital for the human body and researchers have shown that in the past. This is why lack of iron is a nutritional problem which needs to be eliminated [19]. In fact, iron deficiency such as anaemia is a common nutritional problem for people with kidney diseases [20,21]. Similarly, overload of iron can occur when the human body over absorbs, over consumes and over retains the mineral which also has health implications. As an 
element, iron (Fe) cannot be mineralized by the human body. Therefore, when iron fillings are ingested or consumed as part or contaminants in food, it will not be absorbed or over absorbed. Yet, there can be over load in terms of the quantity of iron fillings in the human alimentary canal. The iron fillings may then remain in the alimentary canal and pose health problems such as central nervous system dysfunction, abdominal pain and cardiac problems $[7,11,22]$ or rejected as part of faecal matter. Perusing the literature, there appears to be no research to establish the presence or otherwise of iron fillings in the alimentary canal or in the human faecal matter of people who consume foods made of flour.

Furthermore, majority of authors consider the iron fillings from the grinding plates as nutritional iron. To indicate the dangers of iron fillings, these researchers cite disorders associated with nutritional iron (Fe). Such disorders are but not limited to iron over-absorption, overload and iron (Fe) deficiency as well as their attendant health problems like hemochromatosis which leads to hepatoma [11, 18, 23] and anaemia [20, 21]. Moreover, almost all authors give the impression that the quantity of iron fillings found in flour necessarily end up in the human body system. Attention is not paid to how most food delicacies obtained from corn flour is prepared. In fact, some of the iron fillings are eliminated during the preparation of particular food delicacy.

Additionally, the presence of iron fillings is not traced directly to the already-made food delicacies we eat. Only recently, Adu et al. (2020) practicalised the presence of iron fillings in flour. They prepared porridge and kenkey with their produced flour and then determined the presence of iron (Fe) in the foods [9]. However, their study does not give the real situation of iron fillings in their foods. For instance, analysis of their maize samples with mortar and pestle (no milling process) revealed the presence of Fe. Perhaps, this is an indication that determining the presence of iron fillings in flour materials and food prepared with flour using Atomic Absorption Spectrometry (AAS) or Instrumental Neutron Activation Analysis (INAA) may include mineral and elemental iron because some Fe could come from the flour material [9, 24-27].

In this study, we investigated the level of iron fillings produced as debris in corn flour during normal milling processes and assessed the contamination of food delicacies prepared with corn flour. Our aim is to report on the possible intake of debris of iron fillings due to the nature of the food delicacies we eat. The specific aim is to influence responsible consumption and production of food (comply with SDG 12) in order to erase hunger (comply with SDG 2). Results of the study will also trigger healthier eating habits to boost and sustain the health and well-being of consumers (comply with SDG 3). Sustainable Development Goals (SDGs) were adopted by the UN in 2015 to end poverty, protect the planet and ensure that people enjoy peace and prosperity by 2030 [28]. The UN thus recognized that development of people must be socially, economically and environmentally sustainable.

\section{Materials and Methods}

\subsection{Materials}

About $6 \mathrm{~kg}$ of corn (maize) representing five bowls was purchased from the old market in Tamale. Commercial grinding machines were used to mill the corn into flour. A pair of new grinding plates was purchased from a vendor in Tamale. Old grinding plates from various commercial milling centers were used to mill corn into flour. Some corn brought by clients to the milling centers was also used and flour from food vendors in the Tamale was equally used. A permanent magnet was used to attract the iron fillings. Electronic weighing scale, bowls and stainless steel stirrer were used as well as a Kitchen blender.

\subsection{Methodology}

\subsubsection{Iron Fillings in Corn Flour}

Locally, there are two ways in which corn flour is produced; the dry process and the wet process.

Milling process was achieved using two different pairs of milling plates; one pair of plates for the wet milling and the other pair of plates for the dry milling. In the dry milling process, the corn is sent to the milling center to be milled after pre-cleaning. Each milling session is achieved in four (4) series of milling steps: the first step involves crushing the dry corn, followed by coarse milling, partial milling and then smooth milling with intermittent cooling processes. The corn flour from this process is used to prepare $\mathrm{TZ}$ and its allied forms. In the wet milling process, the maize is soaked overnight (two days) before milling. For this case, each milling session is achieved in a single milling step to produce either a 'wet-whitish' flour for preparing TZ or a 'whitishpaste' or 'corn dough' for preparing Banku and Kenkey.

We determined the amount of iron fillings in this study by creating four (4) scenarios. In the first scenario (Scenario 1), the amount of iron fillings was tracked using the weight loss of the grinding plates (Table 1). For the second scenario (Scenario 2), the amount of iron fillings was determined using a permanent magnet (Table 2). In the third scenario (Scenario 3 ), the daily production of iron fillings was also determined using the permanent magnet over a week (Table 3). For the fourth (Scenario 4), the amount of iron fillings likely to be consumed by an individual from local food delicacies was estimated using a permanent magnet (e.g. Table 4).

\subsubsection{Sample Collection and Preparation}

For the batch-milling operations (dry or wet), the weight of corn brought to the shop by each client was measured before milling. Two hundred and fifty grams $(250 \mathrm{~g})$ aliquot of the flour (from dry or wet milling) from the bottom of the basing (used in collecting the client's flour) was collected from each client with their permission after agitating and scoping. The sample flour was replaced each time with $250 \mathrm{~g}$ of the raw corn we purchased. All the sampled flour was added at the end of the day and thoroughly mixed to obtain an average daily sample. Meanwhile, $200 \mathrm{~g}$ aliquot of the average daily sample was again taken from the bottom of the container 
after another agitating and scoping, water was added, stirred and allowed to settle before decantation. The addition of water and decantation was repeated severally until all the flour was removed to reveal the debris of iron fillings and other materials (mostly stones). This decantation process was done to confirm the presence of the iron fillings due to the worn-out grinding plates. Note that the grinding plates and milling machines were cleaned with ethanol and distilled water to remove contaminants before commencement of the milling processes. Furthermore, the milling machines and grinding plates were cleaned after each batch milling to ensure that all the corn flour and potential iron fillings were collected and before weighing. Worn-out plates were determined by the millers through personal experience and complaints from clients. This occurred when the desired corn flour smoothness was observed not to have been achieved.

\section{Results and Discussions}

Iron ( $\mathrm{Fe}$ ) fillings (metal debris) are insoluble and may thus, undergo corrosion to form rust in the human body [9]. This corrosion can alter the $\mathrm{pH}$ of the body system and can interfere with metabolism and hence have negative impact on human health [18].

\subsection{Scenario 1: Iron Fillings from Weight Loss of Grinding Plates}

We determined the amount of iron fillings from four (4) scenarios as stated above. The amount of iron fillings was estimated using the weight loss of the grinding plates (Table 1) in the first scenario (Scenario 1). Operationally, the burrs of the grinding plates do wear as stated in the introduction. When the plates wear out, they are re-sharpened to create new burrs (Figure 2d) for further milling. Therefore, if the weight (in $\mathrm{kg}$ or $\mathrm{g}$ ) of the grinding plates (both stationary and rotatory) before milling operations (in other words, after resharpening) is known and then the weight of the plates (in $\mathrm{kg}$ or g) immediately after wear-out is also known, it will be possible to determine the amount of metal debris from the grinding plates (in $\mathrm{kg}$ or $\mathrm{g}$ ). This implies that if the total amount of corm milled (in $\mathrm{kg}$ or $\mathrm{g}$ ) at a time period in which the grinding plates got worn-out (in $\mathrm{kg}$ or $\mathrm{g}$ ) is known, the amount of iron fillings (in $\mathrm{kg}$ or $\mathrm{g}$ ) which is likely to be found in an amount of corn flour (in $\mathrm{kg}$ or $\mathrm{g}$ ) milled can also be determined. Based on the above premise, we then conducted the following experiments in several milling shops (with the permission of the shop owners and the clients who visited the milling shops) to investigate the claim.

The weight of the pairs of grinding plates were taken before commencement of milling operations and the final weight of the grinding plates were also taken at the end of milling operations. The plates were categorised as New $(\mathrm{N})$, Fairly New (FN), Fairly Old (FO), and Old (O) plates depending on the number of times the plates were resharpened. A set of plate consist of two (2) pairs of grinding faces: 1) the stationary face denoted as $F_{S}$ and 2) the rotatory face denoted as $F_{R}$. For instance, a Fairly New grinding plate has a stationary face $\left(\mathrm{F}_{\mathrm{SFN}}\right)$ and a rotatory face $\left(\mathrm{F}_{\mathrm{RFN}}\right)$.

The weight loss (WL) of the new plates or the accumulation of iron fillings (AIF) from the new plates was more than those of the old plates (Figure $3 b$ ). Whereas the largest QIF from the new pair of plates was $51.62 \mathrm{~g}$ corresponding to wet milling with a least AIF of $34.53 \mathrm{~g}$ also corresponding to wet milling, the largest AIF from the old pair of plates was $24.74 \mathrm{~g}$ corresponding to dry milling with a least AIF of $18.93 \mathrm{~g}$ also corresponding to dry milling (Table 1). In fact, the largest AIF from the new pair of plates was about two times (2.09) that of the old pair of plates while the least AIF was about one-and-half times (1.80) that of the old pair of plates. These results indicate that corn flour milled with new pair of plates is likely to contain double the amount of Fe than flour milled with old pair of plates. In terms of face (stationary or rotatory) contribution, the largest weight loss (WL) of $26.75 \mathrm{~g}$ came from the rotatory face of a new pair of plates $\left(\mathrm{F}_{\mathrm{RN} 1}\right)$ whereas the least WL of $8.97 \mathrm{~g}$ also came from the rotatory face of an old pair of plates $\left(\mathrm{F}_{\mathrm{RO} 2}\right)$. This indicates that the contribution from the face (AIF) did not follow any definite pattern (Figure 3a). For example, the largest contribution of $26.75 \mathrm{~g}$ from the $1^{\text {st }}$ new plate (New 1) came from the rotatory face $\left(\mathrm{F}_{\mathrm{RN} 1}\right)$ corresponding to wet milling while the largest contribution of $25.51 \mathrm{~g}$ from the $2^{\text {nd }}$ new plate (New 2$)$ came from the stationary face $\left(\mathrm{F}_{\mathrm{SN} 2}\right)$ also corresponding to wet milling. Similarly, the least concentration of $9.33 \mathrm{~g}$ came from the stationary face of the $3^{\text {rd }}$ old plate $\left(\mathrm{F}_{\mathrm{SO} 3}\right)$ corresponding to wet milling but the least concentration of $11.98 \mathrm{~g}$ came from the rotatory face of the $4^{\text {th }}$ old plate $\left(\mathrm{F}_{\mathrm{RO} 4}\right)$ corresponding to dry milling.

On the other hand, analysis of the average concentration of iron fillings $(\mathrm{ACFe})$ revealed that the highest contribution of $0.050 \mathrm{~g} \mathrm{Fe}$ per $\mathrm{kg}$ of corn flour was from the $2^{\text {nd }}$ new plate (New 2) corresponding to dry milling process and the least $\mathrm{ACFe}$ contribution of $0.021 \mathrm{~g} / \mathrm{kg}$ of corn flour was from the $1^{\text {st }}$ old plate (Old 1) corresponding to wet milling process (Figure 3c). In fact, the ACFe from the dry milling process $(0.022-0.050 \mathrm{~g} / \mathrm{kg})$ were more than those from the wet milling processes $\quad(0.021-0.047 \mathrm{~g} / \mathrm{kg})$. The ACFe contribution decreased from the new plates to fairly new plates and then to old plates.

Table 1. Iron fillings from weight loss of grinding plates.

\begin{tabular}{|c|c|c|c|c|c|c|c|c|c|c|}
\hline Plate Type & Plate Face & $W_{1}(\mathrm{~kg})$ & $W_{2}(\mathrm{~kg})$ & $W_{3}(\mathrm{~kg})$ & WL (g) & AIF (g) & NCM & Time (Day) & QCM (bag) & $\mathrm{ACFe}(\mathrm{g} / \mathrm{kg})$ \\
\hline \multirow{2}{*}{ New 1} & $\mathrm{~F}_{\mathrm{SN} 1}$ & 5.0 & 4.9 & 4.87514 & 24.86 & \multirow{2}{*}{51.61} & \multirow{2}{*}{ Wet } & \multirow[t]{2}{*}{7} & \multirow[t]{2}{*}{22} & \multirow{2}{*}{0.04692} \\
\hline & $\mathrm{F}_{\mathrm{RN} 1}$ & 5.0 & 4.8 & 4.77125 & 26.75 & & & & & \\
\hline New 2 & $\begin{array}{l}\mathrm{F}_{\mathrm{SN} 2} \\
\mathrm{~F}_{\mathrm{BN} 2}\end{array}$ & $\begin{array}{l}5.0 \\
5.0\end{array}$ & $\begin{array}{l}4.9 \\
4.8\end{array}$ & $\begin{array}{l}4.87449 \\
4.77505\end{array}$ & $\begin{array}{l}25.51 \\
24.95\end{array}$ & 50.46 & Dry & 7 & 20 & 0.05046 \\
\hline FN 1 & $\mathrm{~F}_{\mathrm{SFN} 1}$ & 4.9 & 4.7 & 4.68006 & 19.94 & 37.01 & Wet & 6 & 19 & 0.03896 \\
\hline
\end{tabular}




\begin{tabular}{|c|c|c|c|c|c|c|c|c|c|c|}
\hline Plate Type & Plate Face & $W_{1}(\mathrm{~kg})$ & $\mathrm{W}_{2}(\mathrm{~kg})$ & $W_{3}(\mathrm{~kg})$ & WL (g) & AIF (g) & NCM & Time (Day) & QCM (bag) & $\mathrm{ACFe}(\mathrm{g} / \mathrm{kg})$ \\
\hline \multirow{3}{*}{ FN 2} & $\mathrm{~F}_{\mathrm{RFN} 1}$ & 4.8 & 4.7 & 4.68293 & 17.07 & & \multirow{3}{*}{ Dry } & \multirow{3}{*}{6} & & \multirow{3}{*}{0.04026} \\
\hline & $\mathrm{F}_{\mathrm{SFN} 2}$ & 4.9 & 4.8 & 4.78253 & 17.47 & \multirow{2}{*}{36.23} & & & \multirow{2}{*}{18} & \\
\hline & $\mathrm{F}_{\mathrm{RFN} 2}$ & 4.8 & 4.6 & 4.58124 & 18.76 & & & & & \\
\hline \multirow{2}{*}{ FN 3} & $\mathrm{~F}_{\mathrm{SFN} 3}$ & 4.9 & 4.6 & 4.58304 & 16.96 & \multirow{2}{*}{34.53} & \multirow{2}{*}{ Wet } & \multirow{2}{*}{6} & \multirow{2}{*}{19} & \multirow{2}{*}{0.03635} \\
\hline & $\mathrm{F}_{\mathrm{RFN} 3}$ & 4.6 & 4.5 & 4.48243 & 17.57 & & & & & \\
\hline \multirow{2}{*}{ FN 4} & $\mathrm{~F}_{\mathrm{SFN} 4}$ & 4.7 & 4.6 & 4.58111 & 18.89 & \multirow{2}{*}{35.71} & \multirow{2}{*}{ Dry } & \multirow[b]{2}{*}{6} & \multirow{2}{*}{18} & \multirow{2}{*}{0.039678} \\
\hline & $\mathrm{F}_{\mathrm{RFN} 4}$ & 4.5 & 4.3 & 4.28318 & 16.82 & & & & & \\
\hline \multirow{2}{*}{ Old 1} & $\mathrm{~F}_{\mathrm{SO} 1}$ & NA & 3.7 & 3.68966 & 10.34 & \multirow{2}{*}{21.88} & \multirow{2}{*}{ Wet } & \multirow{2}{*}{6} & \multirow{2}{*}{20} & \multirow{2}{*}{0.02188} \\
\hline & $\mathrm{F}_{\mathrm{RO} 1}$ & NA & 3.6 & 3.58846 & 11.54 & & & & & \\
\hline \multirow{2}{*}{ Old 2} & $\mathrm{~F}_{\mathrm{SO} 2}$ & NA & 3.4 & 3.39004 & 9.96 & \multirow{2}{*}{18.93} & \multirow{2}{*}{ Dry } & \multirow{2}{*}{6} & \multirow{2}{*}{17} & \multirow{2}{*}{0.02223} \\
\hline & $\mathrm{F}_{\mathrm{RO} 2}$ & NA & 3.5 & 3.49103 & 8.97 & & & & & \\
\hline \multirow{2}{*}{ Old 3} & $\mathrm{~F}_{\mathrm{SO}}$ & NA & 3.4 & 3.39067 & 9.33 & \multirow{2}{*}{19.36} & \multirow{2}{*}{ Wet } & \multirow{2}{*}{6} & \multirow{2}{*}{15} & \multirow{2}{*}{0.02581} \\
\hline & $\mathrm{F}_{\mathrm{RO} 3}$ & NA & 3.3 & 3.28997 & 10.03 & & & & & \\
\hline & $\mathrm{F}_{\mathrm{SO} 4}$ & NA & 3.2 & 3.18724 & 12.76 & & & & & \\
\hline Old 4 & $\mathrm{~F}_{\mathrm{RO} 4}$ & NA & 3.3 & 3.28802 & 11.98 & 24.74 & Dry & 6 & 16 & 0.03093 \\
\hline
\end{tabular}

NB: Net weight of a bag of maize is $50 \mathrm{~kg}$; A bag of maize contains approximately 40 bowls of maize; 1bowl is about $1.26 \mathrm{~kg}$; $F_{R}$ is the rotating face of the grinding plate in the milling compartment; $\mathrm{F}_{\mathrm{S}}$ is the stationary face of the grinding plate in the milling compartment; $\mathrm{W}_{1}$ is the weight of new or blunt plate before sharpening or re-sharpening; $\mathrm{W}_{2}$ is the weight of plate after sharpening (new) or re-sharpening (fairly new and old); $\mathrm{W}_{3}$ is the weight of plate used for the milling operations after sharpening or re-sharpening; WL is the weight loss of grinding plate after final milling operations $\left(\mathrm{WL}=\mathrm{W}_{2}-\mathrm{W}_{3}\right)$; $\mathrm{NCM}$ is the nature of corn milled; QCM is the quantity of corn milled; AIF is the accumulation of iron fillings; ACFe is the average concentration of iron fillings; NA is not applicable because the plates were already re-sharpened by the shop attendants; New pairs of grinding plates were purchased for this exercise but they were blunt and had to be sharpened before it could be used; Fairly new and Old plates were plates used by the millers over time; New plates were sharpened 1 time; Fairly new plates were re-sharpened 2 times and Old plates were re-sharpened 3 times.

The average concentration of iron fillings (ACFe) appears to contradict those of the total accumulation of iron fillings (AIF); the values did not follow any definite pattern. However, this is understandable because the ACFe values were calculated using the quantity of corm bags milled (QCM) over the operational period. For instance, Fe of $51.61 \mathrm{~g}$ from QCM of 22 bags yielded $0.047 \mathrm{~g} / \mathrm{kg}$ flour whereas Fe of $50.46 \mathrm{~g}$ from QCM of 20 bags gave $0.050 \mathrm{~g} / \mathrm{kg}$ flour (Table 1). In fact, our results contradict the findings of a similar study conducted in Nigeria. In the said study, the wet milling process yielded the highest $\mathrm{Fe}$ accumulation compared to the dry milling process (Adeti, 2015). However, another study in Ghana found that the dry milling process produced more Fe accumulation than the wet milling [9]. Our findings are in conformity with the work of the Ghanaian researchers. The reason for the more Fe accumulation from the dry milling was attributed to the fact that the dry milling was done in a series of four (4) milling activities compared to the single milling activity for the wet process $[8,9]$. Another reason is that the wet milling reduced the frictional effect on the grinding plates (perhaps, the water served as lubricant) which leads to less wear and produced less iron fillings accordingly. This showed that wet milling is a safer choice for producing corn flour than dry milling $[8,9]$.
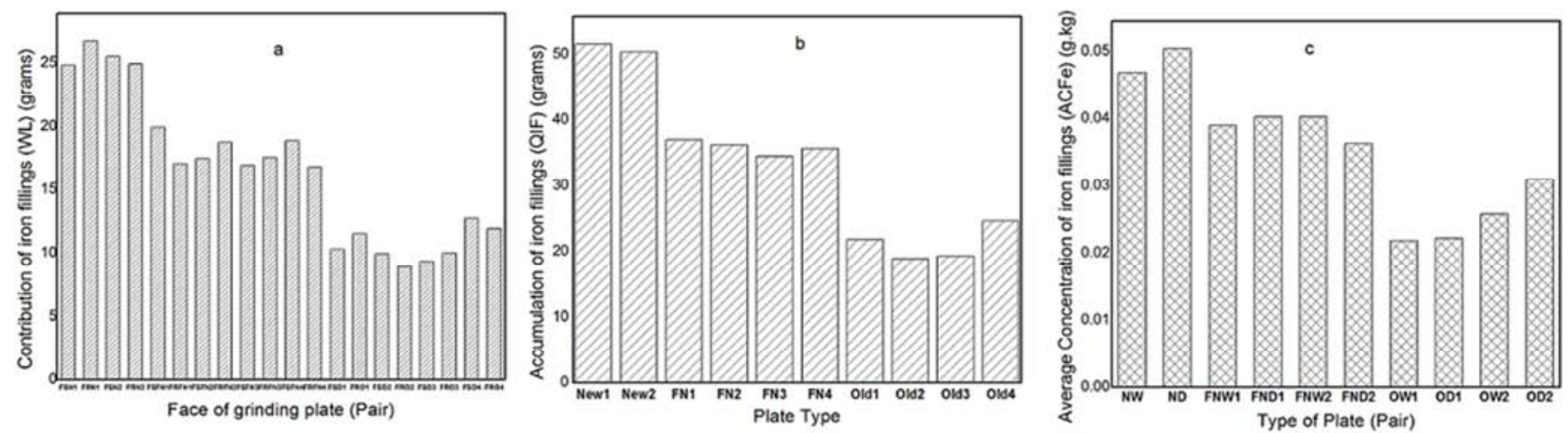

Figure 3. Iron accumulation from weight loss of grinding plates in scenario 1; a): AIF from the face did not follow any definite pattern, b): wet milling produced more AIF from new plates, c): wet milling is a safer choice for producing corn flour than dry milling.

\subsection{Scenario 2: Iron Fillings Attracted with a Permanent Magnet}

For the second scenario (Scenario 2), the accumulation of iron fillings was estimated using a permanent magnet (Table 2). A permanent magnet attached to a metal bar was used to stir each batch of the milled corn flour (from dry process) or dough (wet process) continuously for 20 minutes to attract the iron fillings. This process was repeated two (2) times for each batch until iron fillings could no longer be attracted by the magnet. The amount of iron filings $(\mathrm{Fe})$ attracted to the magnet was removed each time and weighed and the cumulative value finally determined. To ensure that all the iron fillings in each batched were removed, the corn flour or dough was carefully agitated (after the initial Fe attraction) to cause any possible remaining iron fillings to settle at the 
bottom of the basin before scoping. After this, $100 \mathrm{~g}$ of the corn flour or dough at the bottom of each basin was collected and labeled. Water (not measured) was added to this bottom corn flour or dough, stirred for about 20 minutes and allowed to settle before decantation. The decantation process was repeated severally until no trace of the flour or dough could be seen and then the magnet was again used to try to attract any possible 'escapee' iron fillings. In all cases, stone debris was seen without any 'escapee' iron fillings, indicating that the attraction process was effective.

Table 2. Iron fillings attracted with a permanent magnet.

\begin{tabular}{|c|c|c|c|c|c|c|}
\hline Plate Type & Plate Face & NCM & Time (Day) & QCM (bag) & $\mathrm{Fe}(\mathrm{g})$ & $\mathrm{ACFe}(\mathrm{g} / \mathrm{kg})$ \\
\hline New 1 & $\begin{array}{l}F_{\mathrm{SN} 1} \\
F_{\mathrm{RN} 1}\end{array}$ & Wet & 7 & 26 & 53.76 & 0.04785 \\
\hline New 2 & $\begin{array}{l}\mathrm{F}_{\mathrm{SN} 2} \\
\mathrm{~F}_{\mathrm{RN} 2}\end{array}$ & Dry & 7 & 25 & 52.63 & 0.05376 \\
\hline Fairly new 1 & $\begin{array}{l}F_{\mathrm{SFN} 1} \\
F_{\mathrm{RFN} 1}\end{array}$ & Wet & 6 & 19 & 39.15 & 0.03839 \\
\hline Fairly new 2 & $\begin{array}{l}\mathrm{F}_{\mathrm{SFN} 2} \\
\mathrm{~F}_{\mathrm{RFN} 2}\end{array}$ & Dry & 6 & 18 & 38.39 & 0.04121 \\
\hline Old 1 & $\begin{array}{l}\mathrm{F}_{\mathrm{SO} 1} \\
\mathrm{~F}_{\mathrm{RO} 1}\end{array}$ & Wet & 6 & 15 & 25.17 & 0.02737 \\
\hline Old 2 & $\begin{array}{l}\mathrm{F}_{\mathrm{SO} 2} \\
\mathrm{~F}_{\mathrm{RO} 2}\end{array}$ & Dry & 6 & 16 & 22.53 & 0.03146 \\
\hline
\end{tabular}

NB: Net weight $50 \mathrm{~kg}$ per bag; 1bag of maize contains approximately 40 bowls of maize; 1bowl is about $1.26 \mathrm{~kg}$; $\mathrm{F}_{\mathrm{R}}$ is the rotating face of the grinding plate in the milling compartment; $\mathrm{F}_{\mathrm{S}}$ is the stationary face of the grinding plate in the milling compartment; NCM is the nature of corn milled; QCM is the quantity of corn flour milled; Fe is quantity of iron fillings; ACFe is the average concentration of iron; New pairs of grinding plates were purchased for this exercise but they were blunt and had to be sharpened before it could be used; All other plates were plates used by the millers over time.

For this case, the accumulation of iron filling $(\mathrm{Fe})$ in the flour increased from new plates to fairly new plates and then to old plates (Table 2). The largest Fe amount of 53.76g came from the $2^{\text {nd }}$ new plate (New 2) corresponding to dry milling process whereas the least $\mathrm{Fe}$ amount of $22.53 \mathrm{~g}$ was from the $1^{\text {st }}$ old plate (Old 1) corresponding to wet milling process. The results also revealed that the dry milling processes yielded more $\mathrm{Fe}$ than the wet processes (Figure 4a). This finding conforms to the phenomenon in scenario 1 where the

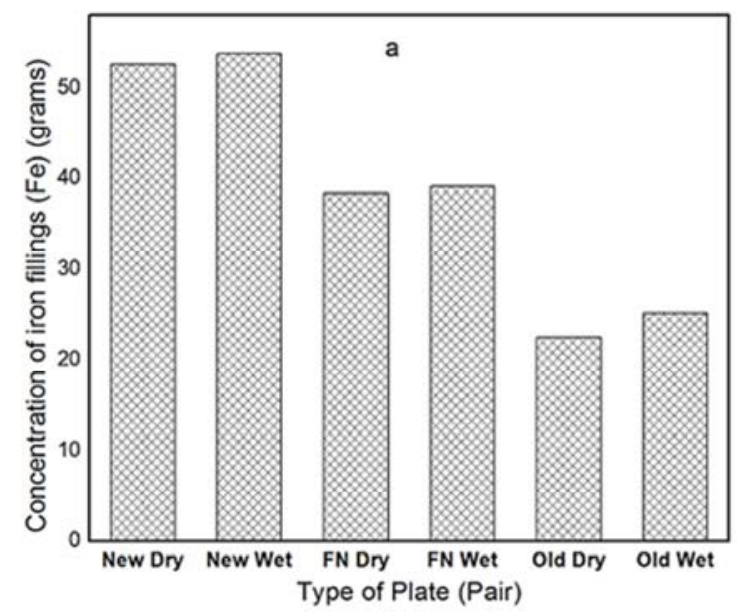

dry milling gave more $\mathrm{Fe}$ accumulation and concentration than the wet milling. Therefore, attracting the Fe with the magnet gave results which were similar to those observed when we tracked the Fe produced due to weight loss of the grinding plates (Figure 4b). However, the use of the magnet yielded more Fe as well as ACFe (Table 2) than the weight loss (Table 1). This may be attributed to the presence of some metallic materials in the maize grains.

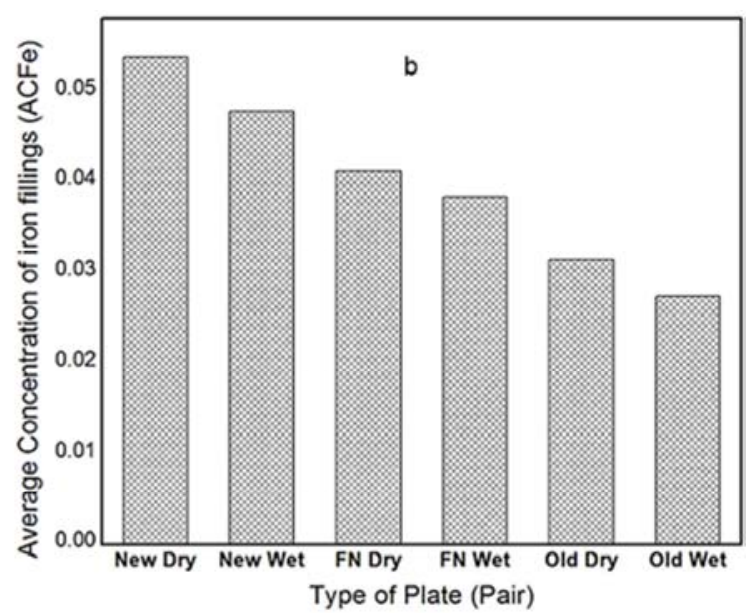

Figure 4. Iron fillings attracted with a permanent magnet in scenario 2; a): Fe from wet milling is more than Fe from dry milling, b): ACFe from wet milling is more than ACFe from dry milling; wet milling is safer for producing corn flour than dry milling.

\subsection{Scenario 3: Daily Production of Iron Fillings}

In the third scenario (Scenario 3), the amount of iron fillings $(\mathrm{Fe})$ produced daily in the corn flour was estimated from weight loss of grinding plates (Table 3). This was achieved by tracking the weight loss of four (4) grinding plates: 1) New pair of Plates; 2) Fairly New pair of Plates; 3)
Fairly Old pair of Plates; and 4) Old pair of Plates. The weight of each pair of grinding plates were measured before milling operations each day for a week (Table 3 ) and the results are presented in Table 4.

The largest amount of Fe was produced within the first 3 days after re-sharpening. For instance, the new pair of grinding plates lost $17.87 \mathrm{~g}$ weight on the $1^{\text {st }}$ day, $13.40 \mathrm{~g}$ on 
the $2^{\text {nd }}$ day and $8.93 \mathrm{~g}$ on the $3^{\text {rd }}$ day. Similarly, the plates lost $6.70 \mathrm{~g}$ weight on the $4^{\text {th }}$ day, $4.47 \mathrm{~g}$ on the $5^{\text {th }}$ day and $2.24 \mathrm{~g}$ on the last day. These values were the highest compared to those from the other pair of plates indicating that the newer the pair of grinding plates, the larger the accumulation of iron fillings after re-sharpening. On the $1^{\text {st }}$ day for example, the new pair of plates yielded $17.87 \mathrm{~g}$ of Fe; the fairly new pair of plates gave $11.82 \mathrm{~g} \mathrm{Fe}$; the fairly old pair of plates produced $3.51 \mathrm{~g}$ $\mathrm{Fe}$; and the old pair of plates yielded $2.24 \mathrm{~g}$ Fe.

Table 3. Daily weight loss of pair of grinding plates tracked over a week.

\begin{tabular}{|c|c|c|c|c|c|c|c|c|}
\hline Plate Type & Plate Face & D1 (kg) & D2 (kg) & D3 (kg) & D4 (kg) & D5 (kg) & D6 (kg) & D7 (kg) \\
\hline \multirow{2}{*}{ New } & $\mathrm{F}_{\mathrm{SN}}$ & 4.90 & 4.89171 & 4.88550 & 4.88136 & 4.87825 & 4.87618 & 4.87514 \\
\hline & $\mathrm{F}_{\mathrm{RN}}$ & 4.80 & 4.79042 & 4.78323 & 4.77844 & 4.77485 & 4.77245 & 4.77325 \\
\hline \multirow{2}{*}{$\mathrm{FN}$} & $\mathrm{F}_{\mathrm{SFN}}$ & 4.70 & 4.89383 & 4.88921 & 4.88613 & 4.88381 & 4.88227 & 4.68006 \\
\hline & $\mathrm{F}_{\mathrm{RFN}}$ & 4.70 & 4.79435 & 4.79011 & 4.78729 & 4.78517 & 4.78376 & 4.68293 \\
\hline \multirow{2}{*}{ FO } & $\mathrm{F}_{\mathrm{SFO}}$ & 3.60 & 3.59848 & 3.59733 & 3.59656 & 3.59600 & 3.59562 & 3.58846 \\
\hline & $\mathrm{F}_{\mathrm{RFO}}$ & 3.70 & 3.69801 & 3.69652 & 3.69553 & 3.69479 & 3.69429 & 3.68966 \\
\hline Old & $\mathrm{F}_{\mathrm{SO}}$ & 3.40 & 3.39870 & 3.39773 & 3.39708 & 3.39660 & 3.39627 & 3.39004 \\
\hline
\end{tabular}

$\mathrm{NB}: \mathrm{F}_{\mathrm{R}}$ is the rotating face of the grinding plate in the milling compartment; $\mathrm{F}_{\mathrm{S}}$ is the stationary face of the grinding plate in the milling compartment; $\mathrm{D}$ is the number of day; QCM is the quantity of corn milled; QIF is the quantity of iron fillings obtained.

The average concentration of iron fillings (ACFe) contributed by the new pair of plates was $8.60 \mathrm{~g}$; that from the fairly new pair of plates was $5.90 \mathrm{~g}$; the fairly old pair of plates gave 1.76g; and the old pair of plates yielded ACFe of $1.12 \mathrm{~g}$. This confirms that a new pair of plates is likely to produce more Fe than an old pair of plates; about 8 folds $(8.60 \mathrm{~g} \div 1.12 \mathrm{~g})$. Furthermore, the new pair of plates produced $13.40 \mathrm{~g}$ average Fe within the $1^{\text {st }}$ three (3) days of operation and $4.47 \mathrm{~g}$ average Fe within the last three (3) days of operation. This shows that a new pair of plates is likely to produce about 3 folds $(13.40 \mathrm{~g} \div 4.47 \mathrm{~g}=2.997)$ Fe within the $1^{\text {st }}$ three (3) days of operation. Similarly, the old pair of plates

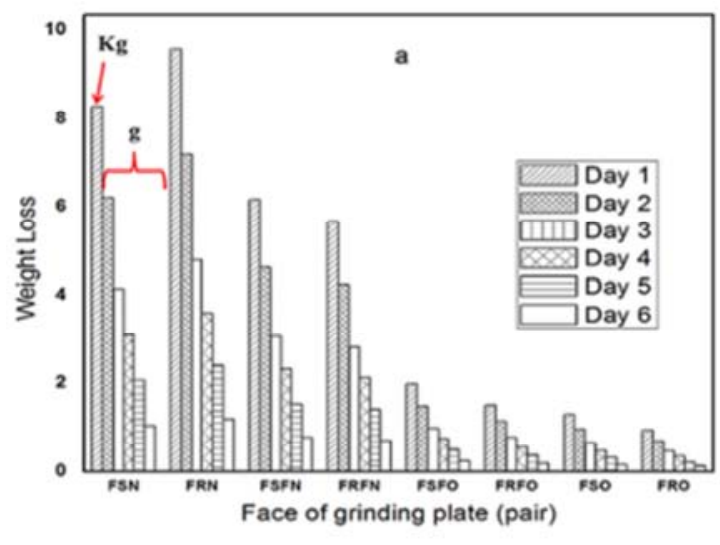

yielded $1.68 \mathrm{~g}$ average $\mathrm{Fe}$ within the $1^{\text {st }}$ three (3) days of operation and $0.56 \mathrm{~g}$ average Fe within the last three (3) days of operation indicating that the old pair of plates is also likely to produce about 3 folds $(1.68 \mathrm{~g} \div 0.56 \mathrm{~g}=3) \mathrm{Fe}$ within the $1^{\text {st }}$ three (3) days of operation. These results indicate that irrespective of the type of grinding plate used, visiting the milling shop 3 days after a pair of grinding plates are resharpened will result to less Fe accumulation in milled flour; in fact, about three (3) folds less. The difficulty however is that, clients have no access to information on the resharpening of grinding plates.

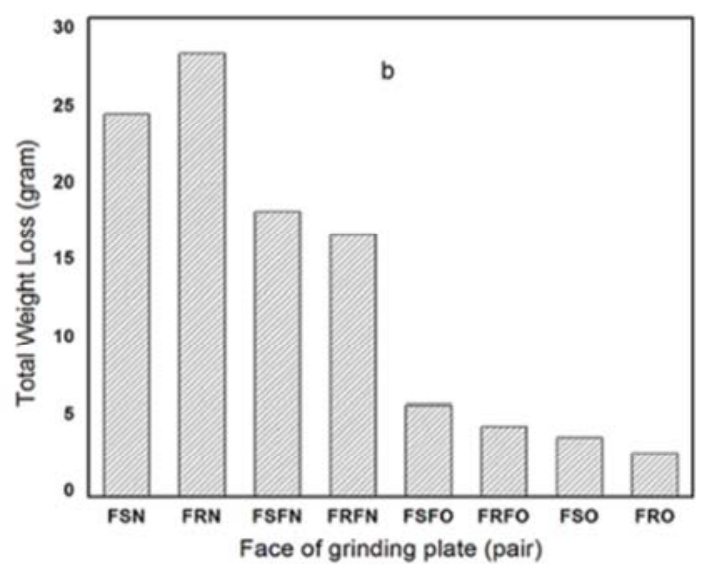

Figure 5. Iron fillings produced daily in corn flour from weight loss of grinding plates.

Table 4. Iron fillings produced daily in corn flour from weight loss of grinding plates.

\begin{tabular}{|c|c|c|c|c|c|c|c|c|c|c|c|}
\hline Plate Type & Plate Face & D1 (kg) & D2 (g) & D3 (g) & D4 (g) & D5 (g) & D6 (g) & D7 (g) & TFC (g) & $\mathrm{CFe}(\mathrm{g})$ & Ave (g) \\
\hline \multirow{2}{*}{ New } & $\mathrm{F}_{\mathrm{SN}}$ & 4.90 & 8.29 & 6.21 & 4.14 & 3.11 & 2.07 & 1.04 & 24.86 & \multirow{2}{*}{51.61} & \multirow{2}{*}{8.60} \\
\hline & $\mathrm{F}_{\mathrm{RN}}$ & 4.80 & 9.58 & 7.19 & 4.79 & 3.59 & 2.40 & 1.20 & 26.75 & & \\
\hline \multirow{2}{*}{$\mathrm{FN}$} & $\mathrm{F}_{\mathrm{SFN}}$ & 4.90 & 6.17 & 4.62 & 3.08 & 2.32 & 1.54 & 0.77 & 18.50 & \multirow{2}{*}{35.45} & \multirow{2}{*}{5.90} \\
\hline & $\mathrm{F}_{\mathrm{RFN}}$ & 4.80 & 5.65 & 4.24 & 2.82 & 2.12 & 1.41 & 0.71 & 16.95 & & \\
\hline \multirow{2}{*}{ FO } & $\mathrm{F}_{\mathrm{SFO}}$ & 3.70 & 1.99 & 1.49 & 0.99 & 0.74 & 0.50 & 0.25 & 5.96 & \multirow{2}{*}{10.53} & \multirow{2}{*}{1.76} \\
\hline & $\mathrm{F}_{\mathrm{RFO}}$ & 3.60 & 1.52 & 1.15 & 0.77 & 0.56 & 0.38 & 0.19 & 4.57 & & \\
\hline \multirow{2}{*}{ Old } & $\mathrm{F}_{\mathrm{SO}}$ & 3.40 & 1.30 & 0.97 & 0.65 & 0.48 & 0.33 & 0.16 & 3.89 & \multirow{2}{*}{6.71} & \multirow{2}{*}{1.12} \\
\hline & $\mathrm{F}_{\mathrm{RO}}$ & 3.50 & 0.94 & 0.70 & 0.47 & 0.36 & 0.23 & 0.12 & 2.82 & & \\
\hline
\end{tabular}

$\mathrm{NB}: \mathrm{F}_{\mathrm{R}}$ is the rotatory face of the grinding plate in the milling compartment; $\mathrm{F}_{\mathrm{S}}$ is the stationary face of the grinding plate in the milling compartment; $\mathrm{D}$ is the number of day; TFC is the total face contribution; Ave is the average Fe contribution over the week: Ave $=\mathrm{TFC} \div \mathrm{Number}$ of days. 


\subsection{Scenario 4: Consumption of Iron Fillings}

For the fourth scenario (Scenario 4), the likely consumption of iron fillings from local food delicacies in the Tamale Metropolis was determined using a permanent magnet.

\subsubsection{Food Delicacy}

In Ghana, food preparation is dominated by the use of grains and cereals which are enjoyed with or without soup (vegetables, leaves or herbs). The various food delicacies in this study were purchased from food vendors or obtained from households in the Tamale Metropolis. The food samples were blended and homogenized with a kitchen blender. Thereafter, plenty water was added to submerge the blended sample in each case and decanted. The addition of water and decantation processes was repeated severally until there was no trace of the food samples. The accumulation of Fe was similarly determined with the permanent magnet after decantation.

\subsubsection{Porridge (KoKo)}

Koko or porridge is a typical Dagbamba (Dagbamba usually written as Dagomba is a tribe in Northern Ghana) delicacy usually taken as breakfast or lunch. In preparing koko or porridge, corn flour or millet flour or mixture of corn and millet flours milled with ingredients (ginger, pepper) is soaked overnight (Figure $6 \mathrm{a}_{4}$ ) to allow for fermentation. Thereafter, the soaked flour is mixed with water (Figure $6 \mathrm{a}_{2}$ ) and strained with a sieve-like clothe (Figure $6 \mathrm{~b}$ ) to separate the liquid (juice) from the solid residue or chaff (Figure $6 a_{1}$ ). The strained juice is then put on fire to boil (Figure 6c) with continued stirring to whisk lumps out in order to have a smooth and nice porridge (Figure 6d).

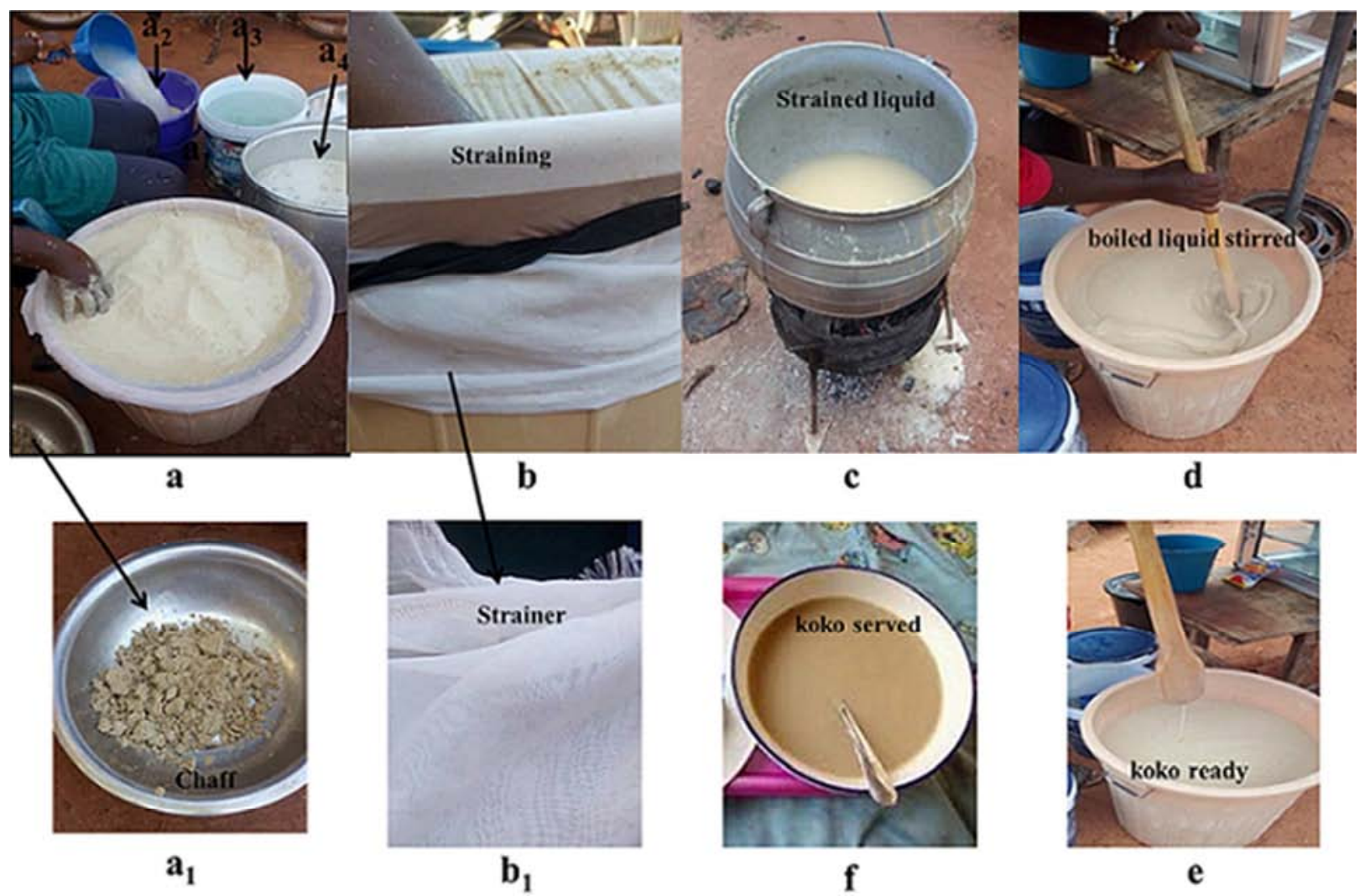

Figure 6. Procedure for preparing koko (porridge) from corn flour.

For the analysis, porridge samples were purchased from some randomly selected vendors. Prior to this, some households were randomly sampled and porridge samples produced for family breakfast were obtained with permission. Typically, so much water was added to a porridge sample and homogenized by stirring. The content was allowed to settle after which the liquid was decanted. This process was repeated severally until there was no trace of the porridge. A permanent magnet was used to attract any possible Fe among the debris at the bottom and weighed (Table 5). The results revealed that there was no trace of iron fillings ( $\mathrm{Fe}$ ) from all the porridge samples from the commercial vendors; this is attributed to the strict quality control measure they observe. The vendors use a sieve-like cloth (Figure $6 b_{1}$ ) or mesh to separate the juice (liquid part of the suspension of the flour) from the solid residue. The sieving allowed the iron fillings to be trapped on the surface of the strainer without entering into the strained liquid (juice). However, analysis of the results of the porridge obtained from the households showed that there were iron fillings $(\mathrm{Fe})$. The largest $\mathrm{Fe}$ accumulation was $0.55 \mathrm{~g}$ and the least was $0.05 \mathrm{~g}$. This translates into about $0.1282 \mathrm{mg} / \mathrm{g}$ least average accumulation and about $1.1957 \mathrm{mg} / \mathrm{g}$ largest average accumulation (Table 5). 
Table 5. Concentration of Iron Fillings in Porridge.

\begin{tabular}{|c|c|c|c|c|c|}
\hline \multirow{2}{*}{ Vendor } & \multirow{2}{*}{ WFD (g) } & \multirow{2}{*}{$\begin{array}{l}\text { Amount } \\
\text { (GHC) }\end{array}$} & \multirow{2}{*}{$\mathrm{Fe}(\mathrm{g})$} & \multicolumn{2}{|l|}{$\mathrm{ACFe}$} \\
\hline & & & & $(g / g)$ & $(\mathrm{mg} / \mathrm{g})$ \\
\hline \multirow{5}{*}{$\mathrm{DV}^{\mathrm{a}}$} & 410.0 & & 0.1 & 0.00024 & 0.2439 \\
\hline & 459.0 & & 0.07 & 0.00015 & 0.1525 \\
\hline & 390.0 & NA & 0.05 & 0.00013 & 0.1282 \\
\hline & $460.0^{c}$ & & $0.55^{\mathrm{c}}$ & $0.00120^{\mathrm{c}}$ & $1.1957^{\mathrm{c}}$ \\
\hline & 395.0 & & 0.31 & 0.00079 & 0.7848 \\
\hline \multirow{25}{*}{$\mathrm{CV}^{\mathrm{b}}$} & 459.0 & 0.5 & 0 & 0 & 0 \\
\hline & 691.5 & 1.0 & 0 & 0 & 0 \\
\hline & 921.0 & 1.5 & 0 & 0 & 0 \\
\hline & 1336.0 & 2.0 & 0 & 0 & 0 \\
\hline & 2393.0 & 3.0 & 0 & 0 & 0 \\
\hline & 487.5 & 0.5 & 0 & 0 & 0 \\
\hline & 646.9 & 1.0 & 0 & 0 & 0 \\
\hline & 979.0 & 1.5 & 0 & 0 & 0 \\
\hline & 1482.4 & 2.0 & 0 & 0 & 0 \\
\hline & 2258.1 & 3.0 & 0 & 0 & 0 \\
\hline & 449.9 & 0.5 & 0 & 0 & 0 \\
\hline & 676.4 & 1.0 & 0 & 0 & 0 \\
\hline & 981.2 & 1.5 & 0 & 0 & 0 \\
\hline & 1436.0 & 2.0 & 0 & 0 & 0 \\
\hline & 2298.7 & 3.0 & 0 & 0 & 0 \\
\hline & 459.0 & 0.5 & 0 & 0 & 0 \\
\hline & 679.8 & 1.0 & 0 & 0 & 0 \\
\hline & 993.0 & 1.5 & 0 & 0 & 0 \\
\hline & 1536.3 & 2.0 & 0 & 0 & 0 \\
\hline & 2196.0 & 3.0 & 0 & 0 & 0 \\
\hline & 454.8 & 0.5 & 0 & 0 & 0 \\
\hline & 698.3 & 1.0 & 0 & 0 & 0 \\
\hline & 971.4 & 1.5 & 0 & 0 & 0 \\
\hline & 1379.2 & 2.0 & 0 & 0 & 0 \\
\hline & 2692.0 & 3.0 & 0 & 0 & 0 \\
\hline
\end{tabular}

adomestic food samples obtained from individual households with permission; ${ }^{b}$ commercial vendors; ${ }^{c}$ this type of koko is made from guinea corn but not the usual maize flour. It is not the preferred koko in Dagbon because the flour is not strained during preparation. Each DV value is an average of five households in five suburbs in the Metropolis. WFD is weight of food delicacy purchased or obtained; Fe is amount of iron fillings in the food delicacy purchased or obtained; ACFe is concentration of iron debris in food delicacy; NA is not applicable-samples were not purchased but obtained with permission.

The results suggest that it is safer to consume porridge from commercial vendors than porridge prepared for domestic consumption. This is attributed to the absence of the strict quality control measure; straining or sieving the juice before use in the domestic preparation (Figures 6a-b). In the domestic preparation of koko, the flour is just mixed with water to form the suspension without straining and continuously stirred on fire to thicken as porridge. Another important issue is the presence of more iron fillings $(1.1957 \mathrm{mg} / \mathrm{g})$ in some of the domestic porridge delicacies. These particular porridge delicacies were made from guinea corn. It is called 'zim buli' in Dagbanli (Dagbanli is the language of the Dagbamba tribe) but which has been nicknamed popularly as 'Mpaga Mynan ma' also in Dagbanli. Both Dagbanli names are derived ironically, from the nature in which this particular porridge delicacy is prepared. For instance, 'zim buli' comes from the fact that in preparing the particular porridge, the guinea corn flour (' $\mathrm{zim}$ ' in Dagbanli) is just fetched and soaked in water ('M buli' in Dagbanli) and allowed to ferment. Thereafter, the porridge is prepared from the soaked (' $M$ buli') guinea corn flour ('zim') earning its name 'zim buli' which literally translates as 'soaked flour'. The nick-name 'Mpag Mynan ma' also comes from the fact that the guinea corn flour is just soaked in water and used to prepare the porridge. Traditionally, porridge is prepared from corn flour or flour from mixture of maize, corn or millet. The flour is then soaked overnight and strained the next morning leaving a residue. The strained liquid is then used to prepare a smooth porridge and the residue is fed to the household animals. Therefore, because the guinea corn flour is just soaked without straining, it does not produce smooth porridge which connotes that the wife is lazy. The fact that husbands traditionally prefer smooth porridge to the one with chaff, a wife ('Paga' in Dagbanli) who prepares this type of porridge for her husband sends signals that the husband cannot 'control' her ('Mynan' in Dagbanli) to prepare for him the preferred smooth porridge. This earns the porridge the nick name 'Mpaga Mynan ma'; which literally means 'I cannot control my wife'. Although majority of the iron fillings are found in the porridge from the households, perhaps, the good thing is that majority (perhaps, over 90\%) of households do not take porridge as breakfast in modern times but tea with bread.

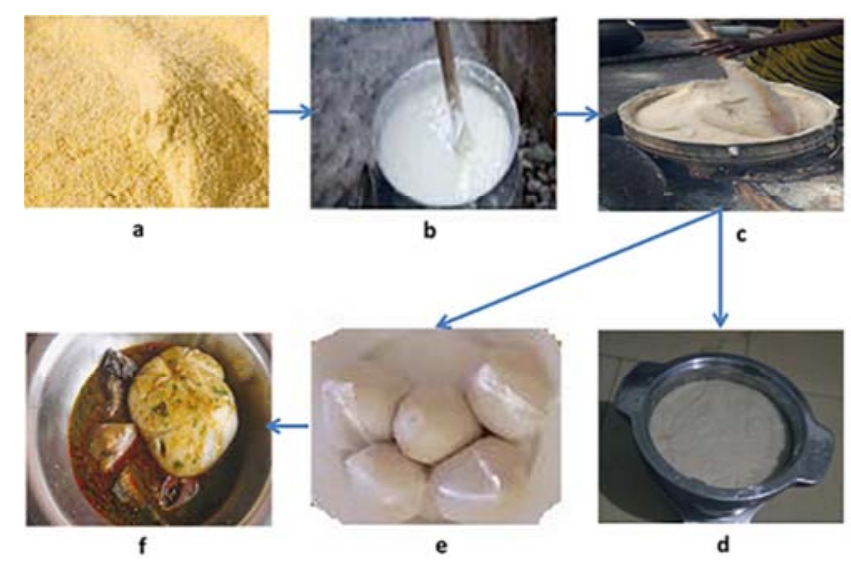

Figure 7. Preparation procedure for 'Sagim' or 'Tuo Zaafi' (TZ). a): corn flour, b): larger suspension allowed to thicken; c): larger suspension kneading with a wooden peddle to avoid lumps; d): solidified domestic TZ; e): d): solidified commercial TZ; f): TZ served with vegetable soup (ayoyo with meat and fish).

\subsubsection{Sagim (TZ)}

'Sagim' is a Dagbanli name for one of the food delicacies prepared from corn (millet, guinea corn) flour (Figure 7a) and enjoyed, usually by people of Northern extraction in Ghana. It is mostly eaten hot, perhaps leading to its popular name ' $T Z$ ' or 'Tuo Zaafi' (stirred hot) in the Hausa language of Nigeria. Briefly, the food is prepared by dispersing the corn flour in water. The suspension is then decanted into hot water in a pot and allowed to boil. An aliquot or portion of the suspension (about $1 / 3$ of the mixture) is reserved to be used later when the suspension thickens undesirably or to avoid lumps. The larger suspension is then kneaded continuously with a wooden peddle (Figure $7 \mathrm{~b}$ ) and fresh solid corn flour is sprinkled intermittently while stirring (kneading) to avoid any lumps until it gradually solidifies 
into a paste or semi-solid (Figure 7c) due to evapouration of water. The semi-solid form is then served as 'Sagim' or ' $T Z$ ' (Figure 7d for domestic; Figure 1e for commercial) and eaten with variety of vegetable soups (Figure 7f).

We categorized the 'Sagim' or 'TZ' vendors into three (3) levels: level $1\left(\mathrm{TZL}_{1}\right)$, level $2\left(\mathrm{TZL}_{2}\right)$ and level $3\left(\mathrm{TZL}_{3}\right)$. $\mathrm{TZL}_{1}$ refer to domestic vendors; these $\mathrm{TZs}$ were prepared for domestic consumption. Each $\mathrm{TZL}_{1}$ values are averages of five (5) typical households in five (5) suburbs in the Metropolis. TZL $\mathrm{L}_{2}$ are 'high class' very popular food vendors randomly selected food vendors in the metropolis. They have very massive patronage. $\mathrm{TZL}_{3}$ are 'low class' food vendors also randomly selected local food vendors in the metropolis. They do not have very large patronage.

Analysis of the results revealed that the accumulation of iron fillings $(\mathrm{Fe})$ increased with increasing quantity of $\mathrm{TZ}$ samples from both the $\mathrm{TZL}_{1}$ (domestic) and $\mathrm{TZL}_{3}$ (low class) vendors. However, the largest accumulation of Fe came from the 'low class' $\left(\mathrm{TZL}_{3}\right)$ vendors $(1.98 \mathrm{~g})$ followed by the domestic $\left(\mathrm{TZL}_{1}\right)$ vendors $(1.15 \mathrm{~g})$ but there was no $\mathrm{Fe}$ accumulation from the food samples purchased from any of the 'high class' $\left(\mathrm{TZL}_{2}\right)$ vendors (Table 6). In fact, the lowest $\mathrm{Fe}$ accumulation from the domestic $\left(\mathrm{TZL}_{1}\right)$ vendors was $0.55 \mathrm{~g}$ with the largest accumulation of $1.15 \mathrm{~g}$ translating into an average $\mathrm{Fe}$ accumulation of $0.95 \mathrm{~g}$. Meanwhile, the least average concentration of iron fillings (ACFe) for this group of vendors $\left(\mathrm{TZL}_{1}\right)$ was $0.96 \mathrm{mg} / \mathrm{g}$ with a largest average concentration of $1.00 \mathrm{mg} / \mathrm{g}$ leading to an average $\mathrm{Fe}$ concentration of $0.90 \mathrm{mg} / \mathrm{g}$. Similarly, the lowest Fe accumulation from the 'low class' $\left(\mathrm{TZL}_{3}\right)$ vendors was $0.54 \mathrm{~g}$ with the largest accumulation of $1.98 \mathrm{~g}$ translating into an average $\mathrm{Fe}$ accumulation of $1.34 \mathrm{~g}$. The least average concentration of iron fillings for 'low class' $\left(\mathrm{TZL}_{3}\right)$ vendors was $0.75 \mathrm{mg} / \mathrm{g}$ and the largest average concentration was $1.30 \mathrm{mg} / \mathrm{g}$ which led to an average $\mathrm{Fe}$ concentration of $0.95 \mathrm{mg} / \mathrm{g}$. Clearly (Table 6), there was no Fe accumulation and hence, no Fe concentration from any of the TZ samples from any of the 'high class' $\left(\mathrm{TZL}_{2}\right)$ vendors. This is attributed to the strict quality control measure observed by these vendors during the preparation of the TZ. After milling, the 'high class' $\left(\mathrm{TZL}_{2}\right)$ vendors sieve the corn flour before it is used to prepare the food.

This singular step is the difference between the preparation procedure of the $\mathrm{TZ}$ samples from both the domestic $\left(\mathrm{TZL}_{1}\right)$ and 'low class' $\left(\mathrm{TZL}_{3}\right)$ and then the 'high class' $\left(\mathrm{TZL}_{2}\right)$ vendors. This is ironic because the domestic $\left(\mathrm{TZL}_{1}\right)$ and 'low class' $\left(\mathrm{TZL}_{3}\right)$ vendors produce less food compared to the 'high class' $\left(\mathrm{TZL}_{2}\right)$ vendors. Yet, it is the 'high class' $\left(\mathrm{TZL}_{2}\right)$ vendors who practice this difficult but rewarding step. The reasons for the absence of the sieving step for the domestic $\left(\mathrm{TZL}_{1}\right)$ and 'low class' ( $\left.\mathrm{TZL}_{3}\right)$ vendors may be two folds: 1 ) lack of knowledge about the possible transfer of the iron debris $(\mathrm{Fe})$ from the milling machines into the corn flour and its transfer into the TZ subsequently. We arrived at this deduction because many women cloud not even guess the presence of iron debris in the flour even though almost all of them were aware that the grinding plates wear and are re- sharpened regularly. 2) shear negligence about the effects of the presence of iron debris $(\mathrm{Fe})$ in the TZ. We gathered that sieving was actually part of the process of preparing TZ in the 'old days' but it has been abandoned in recent times. This is perhaps, due to the tedious nature of producing flour or the increasing nature of household chores.

Table 6. Concentration of Iron Fillings in 'Sagim' or TZ.

\begin{tabular}{|c|c|c|c|c|c|}
\hline \multirow{2}{*}{ Vendor } & \multirow{2}{*}{ WFD (g) } & \multirow{2}{*}{$\begin{array}{l}\text { Amount } \\
\text { (GHC) }\end{array}$} & \multirow{2}{*}{$\mathrm{Fe}(\mathrm{g})$} & \multicolumn{2}{|l|}{ ACFe } \\
\hline & & & & (g/g) & $(\mathrm{mg} / \mathrm{g})$ \\
\hline \multirow{5}{*}{$\mathrm{TZL}_{1}$} & 919.30 & & 0.91 & 0.00099 & 0.99 \\
\hline & 1012.10 & & 1.01 & 0.00100 & 1.00 \\
\hline & 897.00 & NA & 0.55 & 0.00061 & 0.61 \\
\hline & 1200.50 & & 1.15 & 0.00096 & 0.96 \\
\hline & 1149.30 & & 1.11 & 0.00097 & 0.97 \\
\hline \multirow{15}{*}{$\mathrm{TZL}_{2}$} & 510.30 & 1.00 & 0 & 0 & 0 \\
\hline & 1010.50 & 2.00 & 0 & 0 & 0 \\
\hline & 1530.20 & 3.00 & 0 & 0 & 0 \\
\hline & 2040.70 & 4.00 & 0 & 0 & 0 \\
\hline & 2552.50 & 5.00 & 0 & 0 & 0 \\
\hline & 490.10 & 1.00 & 0 & 0 & 0 \\
\hline & 1017.30 & 2.00 & 0 & 0 & 0 \\
\hline & 1601.20 & 3.00 & 0 & 0 & 0 \\
\hline & 2110.40 & 4.00 & 0 & 0 & 0 \\
\hline & 2613.10 & 5.00 & 0 & 0 & 0 \\
\hline & 507.50 & 1.00 & 0 & 0 & 0 \\
\hline & 1022.30 & 2.00 & 0 & 0 & 0 \\
\hline & 1397.0 & 3.00 & 0 & 0 & 0 \\
\hline & 2214.30 & 4.00 & 0 & 0 & 0 \\
\hline & 2741.10 & 5.00 & 0 & 0 & 0 \\
\hline \multirow{10}{*}{$\mathrm{TZL}_{3}$} & 490.8 & 1.00 & 0.54 & 0.00110 & 1.10 \\
\hline & 1034.3 & 2.00 & 1.09 & 0.00105 & 1.05 \\
\hline & 1561.2 & 3.00 & 1.26 & 0.00081 & 0.81 \\
\hline & 2086 & 4.00 & 1.62 & 0.00078 & 0.78 \\
\hline & 2614.1 & 5.00 & 1.96 & 0.00075 & 0.75 \\
\hline & 530.20 & 1.00 & 0.69 & 0.00130 & 1.30 \\
\hline & 1040.30 & 2.00 & 1.12 & 0.00108 & 1.08 \\
\hline & 1459.10 & 3.00 & 1.45 & 0.00099 & 0.99 \\
\hline & 2090.00 & 4.00 & 1.71 & 0.00082 & 0.82 \\
\hline & 2549.70 & 5.00 & 1.98 & 0.00078 & 0.78 \\
\hline
\end{tabular}

NB: $\mathrm{TZL}_{1}$ is domestic vendors: the food samples were obtained from individual households with permission. Each $\mathrm{TZL}_{1}$ value is an average $\mathrm{Fe}$ from five typical households from five different suburbs in the Tamale Metropolis. WFD is weight of food delicacy bought ( $\mathrm{g}$ ); Fe is amount of iron fillings in food delicacy bought $(\mathrm{g})$; $\mathrm{ACFe}$ is rate of iron consumption in food delicacy $(\mathrm{mg} / \mathrm{g})$; NA is not applicable-samples were not purchased but obtained with permission.

The reason for the presence of the sieving step for the 'high class' $\left(\mathrm{TZL}_{2}\right)$ vendors may be due to knowledge about the possible transfer of iron debris into the TZ subsequently. Many of these vendors are aware of the fact that the grinding plates do wear and are re-sharpened regularly. Some of them have actually reported seeing debris settlement at the bottom after dispersing corn flour into water and decanting. Hence, there was the need for them to try and eliminate the metal debris from the corn flour.

\subsubsection{Banku}

Banku is traditionally a staple food for the Ga, Ewe and Fante people of Southern Ghana but which has become a popular Ghanaian delicacy. Banku is made solely from corn dough or from a mixture of milled and fermented corn and 
cassava flours. The corn dough and cassava dough are mixed thoroughly with salted water to form slurry which is put on fire to boil. The mixture on fire is then stirred continuously with a wooden pestle to thicken into dough-like paste (Figure $8 \mathrm{a})$. The dough-like paste is kneaded continuously until it is smooth (Figure 8b). The smooth semi-solid Banku is served (Figure $8 \mathrm{c}$ ) and eaten with variety of soups or stew or pepper with any meat or fish (Figure 8d).
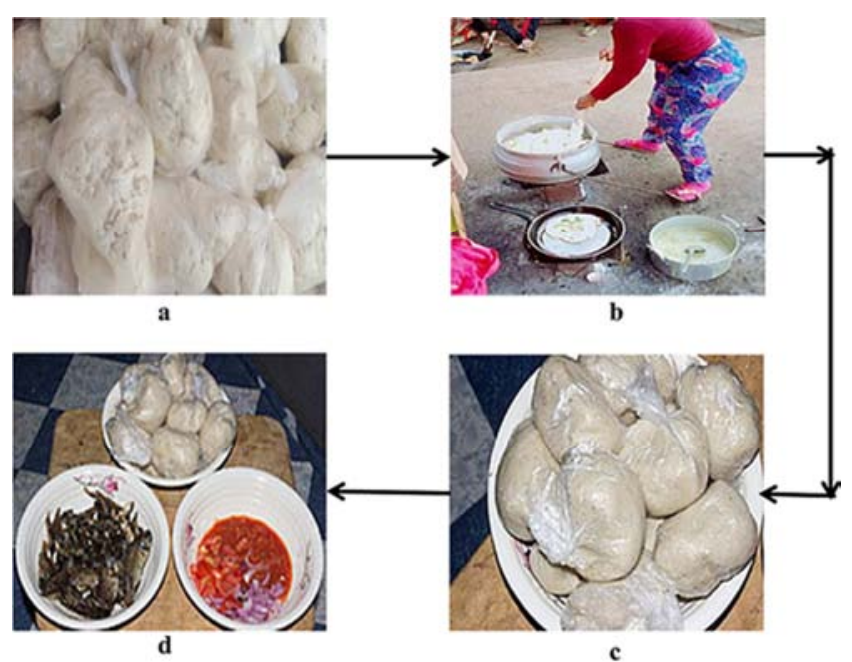

Figure 8. Preparation of banku; a): Corn dough, b): Kneading paste, c: Solid banku, $d$ : Served banku.

As in the previous case, we categorized the banku vendors into three (3) levels: level $1\left(\mathrm{BKL}_{1}\right)$, level $2\left(\mathrm{BKL}_{2}\right)$ and level $3\left(\mathrm{BKL}_{3}\right)$. Level $1\left(\mathrm{BKL}_{1}\right)$ refer to domestic vendors; these banku samples were prepared for domestic consumption. Each level $1\left(\mathrm{BKL}_{1}\right)$ values are averages of five (5) typical households in five (5) suburbs in the Metropolis. Level 2 $\left(\mathrm{BKL}_{2}\right)$ are 'high class' food vendors who were randomly selected popular food vendors in the metropolis who have massive patronage. Level $3\left(\mathrm{BKL}_{3}\right)$ are 'low class' food vendors who were also randomly selected local food vendors in the metropolis but who do not have large patronage.

The results revealed that the accumulation of iron fillings (Fe) increased with increasing quantity of Banku samples (WFD) from the vendors (Table 7). For example, the amount of food sample increased from a minimum of $570.30 \mathrm{~g}$, $580.40 \mathrm{~g}, 670.30 \mathrm{~g}, 780.10 \mathrm{~g}$ to a maximum of $850.20 \mathrm{~g}$ with corresponding increase of $\mathrm{Fe}$ from a minimum of $0.55 \mathrm{~g}$, $0.90 \mathrm{~g}, 1.01 \mathrm{~g}, 1.11 \mathrm{~g}$ to a maximum of $1.15 \mathrm{~g}$ respectively, for the domestic consumers $\left(\mathrm{BKL}_{1}\right)$. However, the average concentration of iron fillings (ACFe) for this group of food samples did not depend on the amount of food samples. For example, as the WFD increased from $570.30 \mathrm{~g}, 580.40 \mathrm{~g}$, $670.30 \mathrm{~g}, 780.10 \mathrm{~g}$ to $850.20 \mathrm{~g}$, the corresponding $\mathrm{ACFe}$ initially increased from $0.9644 \mathrm{mg} / \mathrm{g}$ to $1.5679 \mathrm{mg} / \mathrm{g}$ and then decreased to $1.5068 \mathrm{mg} / \mathrm{g}, 1.4229 \mathrm{mg} / \mathrm{g}$ and to $1.3526 \mathrm{mg} / \mathrm{g}$ respectively. In fact, this phenomenon (Fe depending on increase in WFD but ACFe not depending on increase in WFD) was noticed for almost all the vendors $\left(\mathrm{BKL}_{1}, \mathrm{BKL}_{2}\right.$ and $\left.\mathrm{BKL}_{3}\right)$ except for the $1^{\text {st }}$ group of vendors in level 2 $\left(\mathrm{BKL}_{2}\right)$. For this case, the amount of $\mathrm{Fe}$ increased with increasing amount of WFD but the ACFe decreased with the increasing amount of WFD (entries 5 to 10 in Table 7).

Table 7. Concentration of Iron Fillings in Banku.

\begin{tabular}{|c|c|c|c|c|c|}
\hline \multirow{2}{*}{ Vendor } & \multirow{2}{*}{ WFD (g) } & \multirow{2}{*}{$\begin{array}{l}\text { Amount } \\
\text { (GHC) }\end{array}$} & \multirow{2}{*}{$\mathrm{Fe}(\mathrm{g})$} & \multicolumn{2}{|l|}{$\mathrm{ACFe}$} \\
\hline & & & & (g/g) & $(\mathrm{mg} / \mathrm{g})$ \\
\hline \multirow{5}{*}{$\mathrm{BKL}_{1}$} & 570.30 & \multirow{5}{*}{ NA } & 0.55 & 0.0010 & 0.9644 \\
\hline & 780.10 & & 1.11 & 0.0014 & 1.4229 \\
\hline & 850.20 & & 1.15 & 0.0014 & 1.3526 \\
\hline & 580.40 & & 0.91 & 0.0016 & 1.5679 \\
\hline & 670.30 & & 1.01 & 0.0015 & 1.5068 \\
\hline \multirow{15}{*}{$\mathrm{BKL}_{2}$} & 450.50 & 1.00 & 0.56 & 0.0012 & 1.2431 \\
\hline & 940.30 & 2.00 & 1.13 & 0.0012 & 1.2017 \\
\hline & 1254.10 & 3.00 & 1.23 & 0.0010 & 0.9808 \\
\hline & 1682.60 & 4.00 & 1.57 & 0.0009 & 0.9331 \\
\hline & 2153.10 & 5.00 & 1.86 & 0.0009 & 0.8639 \\
\hline & 590.10 & 1.00 & 0.59 & 0.0010 & 0.9998 \\
\hline & 919.23 & 2.00 & 1.52 & 0.0017 & 1.6536 \\
\hline & 1131.20 & 3.00 & 1.61 & 0.0014 & 1.4233 \\
\hline & 1610.52 & 4.00 & 1.77 & 0.0011 & 1.0990 \\
\hline & 2093.60 & 5.00 & 1.79 & 0.0009 & 0.8550 \\
\hline & 599.30 & 1.00 & 0.39 & 0.0007 & 0.6508 \\
\hline & 983.10 & 2.00 & 1.66 & 0.0017 & 1.6885 \\
\hline & 1297.30 & 3.00 & 1.78 & 0.0014 & 1.3721 \\
\hline & 1578.20 & 4.00 & 1.83 & 0.0012 & 1.1595 \\
\hline & 2107.70 & 5.00 & 1.90 & 0.0009 & 0.9015 \\
\hline \multirow{10}{*}{$\mathrm{BKL}_{3}$} & 591.50 & 1.00 & 0.44 & 0.0007 & 0.7439 \\
\hline & 1004.10 & 2.00 & 1.49 & 0.0015 & 1.4839 \\
\hline & 1354.60 & 3.00 & 1.51 & 0.0011 & 1.1147 \\
\hline & 1689.61 & 4.00 & 1.53 & 0.0009 & 0.9055 \\
\hline & 2054.80 & 5.00 & 1.56 & 0.0008 & 0.7592 \\
\hline & 590.16 & 1.00 & 0.31 & 0.0005 & 0.5253 \\
\hline & 970.20 & 2.00 & 1.52 & 0.0016 & 1.5667 \\
\hline & 1354.82 & 3.00 & 1.69 & 0.0012 & 1.2474 \\
\hline & 1631.30 & 4.00 & 1.85 & 0.0011 & 1.1341 \\
\hline & 2212.51 & 5.00 & 1.93 & 0.0009 & 0.8723 \\
\hline
\end{tabular}

NB: Level $1\left(\mathrm{BKL}_{1}\right)$ are domestic vendors: the food samples were obtained from individual households with permission. Each $\mathrm{BKL}_{1}$ value is an average Fe from five typical households from five different suburbs in the Tamale Metropolis. Level $2\left(\mathrm{BKL}_{2}\right)$ are 'high class' food vendors randomly selected; Level $3\left(\mathrm{BKL}_{3}\right)$ are 'low class' food vendors randomly selected; WFD is weight of food delicacy bought $(\mathrm{g})$; $\mathrm{Fe}$ is amount of iron fillings in food delicacy bought $(\mathrm{g})$; ACFe is rate of iron consumption in food delicacy (mg/g); NA is not applicable-samples were not purchased but obtained with permission.

The presence of $\mathrm{Fe}$ in all the banku samples from all the vendors $\left(\mathrm{BKL}_{1}, \mathrm{BKL}_{2}\right.$ and $\left.\mathrm{BKL}_{3}\right)$ is attributed to lack of quality control measure in preparing the banku dough. The flour for making the dough is not usually sieved as in the case of the corn flour for preparing commercial TZ. Hence, the metal debris $(\mathrm{Fe})$ from the milling plates are carried into the banku samples which are consumed by individuals who eat the banku delicacy eventually.

\subsubsection{Kenkey}

Kenkey is also a typical dish in Ghana made from fermented corn flour. It is a major food for the $\mathrm{Ga}$ and the Fante people (the Ga people call it komi and the Fante people call it dokono) in Southern Ghana but now consumed throughout the country. To prepare kenkey, kenkey dough is usually prepared first: corn flour is combined with corn starch and water is gradually added and kneaded until smooth 
and homogeneous dough is obtained. The dough is then covered and allowed to ferment. The dough is then divided into two and one part is cooked with addition of light salt (Figure 9a). Kneading is continued to prevent the dough from clotting and sticking to the pot. The second part of the dough is incorporated into the cooked part (Figure 9b) until the whole mixture is homogeneous. The cooked dough is divided into portions and rolled into balls (Figure 9c) and then placed in dried corn leaves (Figure 9d). The rolled balls in the dried corn leaves are steamed (Figure 9e) and served as Kenkey (Figure 9f).

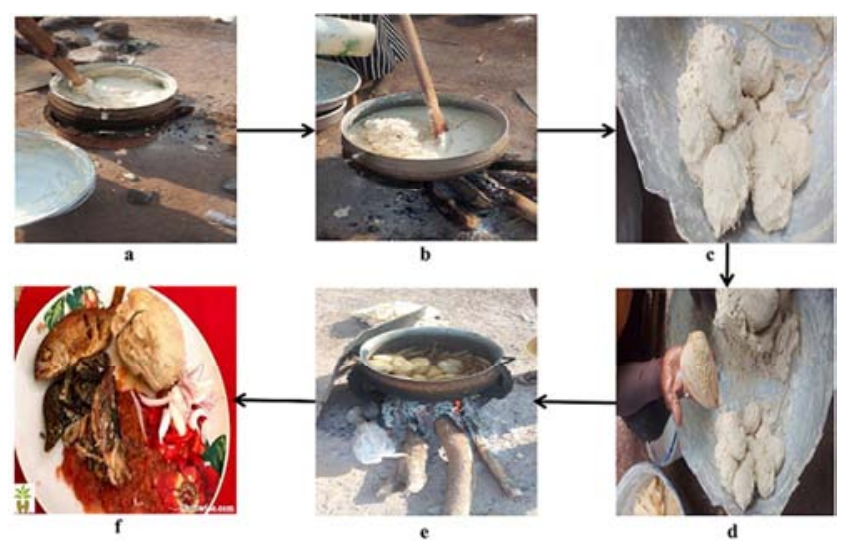

Figure 9. Preparation of kenkey, a: First part of dough cooked, b: Second part of the dough incorporated, $c$ : cooked dough rolled into balls, d: balls in corn leaves, e: balls in leaves steamed, f: Served Kenkey.

We again categorized the Kenkey vendors into three (3) levels: level $1\left(\mathrm{KNL}_{1}\right)$, level $2\left(\mathrm{KNL}_{2}\right)$ and level $3\left(\mathrm{KNL}_{3}\right)$. Level $1\left(\mathrm{KNL}_{1}\right)$ refers to domestic vendors; traditionally, kenkey is not a favourite delicacy for the Dagomba people hence domestic samples could not be obtained. Level 2 $\left(\mathrm{KNL}_{2}\right)$ are 'high class' food vendors; these are randomly selected very popular food vendors in the metropolis. They have very massive patronage. Level $3\left(\mathrm{KNL}_{3}\right)$ are 'low class' food vendors; these are also randomly selected very local food vendors in the metropolis but they do not have very large patronage.

The analysis revealed that the accumulation of iron fillings $(\mathrm{Fe})$ in this case also increased with increasing quantity of Kenkey samples (WFD) from the commercial vendors $\left(\mathrm{KNL}_{2}-\mathrm{KNL}_{3}\right)$. For instance, the amount of food sample increased from a minimum of $303.51 \mathrm{~g}, 530.35 \mathrm{~g}$, $910.21 \mathrm{~g}, \quad 1060.70 \mathrm{~g}$ to a maximum of $1517.50 \mathrm{~g}$ with corresponding increase of $\mathrm{Fe}$ from a minimum of $0.21 \mathrm{~g}$, $0.42 \mathrm{~g}, 1.57 \mathrm{~g}, 1.73 \mathrm{~g}$ to a maximum of $1.78 \mathrm{~g}$ respectively (Table 8). However, the average concentration of iron fillings $(\mathrm{ACFe})$ for these groups $\left(\mathrm{KNL}_{2}-\mathrm{KNL}_{3}\right)$ of food samples did not depend on the amount of food samples. For example, the corresponding ACFe initially increased from $0.69 \mathrm{mg} / \mathrm{g}$ to $0.79 \mathrm{mg} / \mathrm{g}$ and to $1.72 \mathrm{mg} / \mathrm{g}$ but decreased to $1.63 \mathrm{mg} / \mathrm{g}$ and decreased subsequently to $1.17 \mathrm{mg} / \mathrm{g}$ (Table 8 ) respectively. Contrary to the phenomenon observed for the Banku delicacies, the amount of Fe increased with increasing amount of WFD but the ACFe was independent on the increase in WFD in the Kenkey delicacies $\left(\mathrm{KNL}_{2}\right.$ and $\mathrm{KNL}_{3}$ ). Meanwhile, the presence of $\mathrm{Fe}$ in all the Kenkey samples is also attributed to lack of sieving during the preparation of the Kenkey dough.

Table 8. Concentration of Iron Fillings in Kenkey.

\begin{tabular}{|c|c|c|c|c|c|}
\hline \multirow{2}{*}{ Vendor } & \multirow{2}{*}{ WFD (g) } & \multirow{2}{*}{$\begin{array}{l}\text { Amount } \\
\text { (GHC) }\end{array}$} & \multirow{2}{*}{$\mathrm{Fe}(\mathrm{g})$} & \multicolumn{2}{|l|}{ ACFe } \\
\hline & & & & (g/g) & $(\mathrm{mg} / \mathrm{g})$ \\
\hline \multirow{5}{*}{$\mathrm{KNL}_{1}{ }^{\mathrm{a}}$} & 0 & \multirow{5}{*}{ NA } & 0 & 0 & 0 \\
\hline & 0 & & 0 & 0 & 0 \\
\hline & 0 & & 0 & 0 & 0 \\
\hline & 0 & & 0 & 0 & 0 \\
\hline & 0 & & 0 & 0 & 0 \\
\hline \multirow{15}{*}{$\mathrm{KNL}_{2}$} & 303.51 & 1.00 & 0.21 & 0.0007 & 0.69 \\
\hline & 530.35 & 2.00 & 0.42 & 0.0008 & 0.79 \\
\hline & 910.21 & 3.00 & 1.57 & 0.0017 & 1.72 \\
\hline & 1060.70 & 4.00 & 1.73 & 0.0016 & 1.63 \\
\hline & 1517.50 & 5.00 & 1.78 & 0.0012 & 1.17 \\
\hline & 591.30 & 1.00 & 0.57 & 0.0010 & 0.96 \\
\hline & 929.23 & 2.00 & 1.34 & 0.0014 & 1.44 \\
\hline & 1161.10 & 3.00 & 1.53 & 0.0013 & 1.32 \\
\hline & 1616.30 & 4.00 & 1.74 & 0.0011 & 1.08 \\
\hline & 2097.62 & 5.00 & 1.79 & 0.0009 & 0.85 \\
\hline & 413.12 & 1.00 & 0.49 & 0.0012 & 1.19 \\
\hline & 623.52 & 2.00 & 1.01 & 0.0016 & 1.62 \\
\hline & 995.17 & 3.00 & 1.63 & 0.0016 & 1.64 \\
\hline & 1263.27 & 4.00 & 1.77 & 0.0014 & 1.40 \\
\hline & 1596.23 & 5.00 & 1.88 & 0.0012 & 1.18 \\
\hline \multirow{10}{*}{$\mathrm{KNL}_{3}$} & 589.53 & 1.00 & 0.89 & 0.0015 & 1.51 \\
\hline & 973.71 & 2.00 & 1.36 & 0.0014 & 1.40 \\
\hline & 1274.73 & 3.00 & 1.59 & 0.0012 & 1.25 \\
\hline & 1594.12 & 4.00 & 1.69 & 0.0011 & 1.06 \\
\hline & 2122.27 & 5.00 & 1.91 & 0.0009 & 0.90 \\
\hline & 392.23 & 1.00 & 0.58 & 0.0015 & 1.48 \\
\hline & 579.19 & 2.00 & 1.10 & 0.0019 & 1.90 \\
\hline & 993.43 & 3.00 & 1.47 & 0.0015 & 1.48 \\
\hline & 1163.10 & 4.00 & 1.62 & 0.0014 & 1.39 \\
\hline & 1613.40 & 5.00 & 1.67 & 0.0010 & 1.04 \\
\hline
\end{tabular}

${ }^{a} \mathrm{KNL}_{1}$ is domestic vendors: a typical family in the metropolis does not prepare kenkey to eat. Traditionally, kenkey is not a favourite delicacy for the Dagomba people. $\mathrm{KNL}_{2}$ is 'high class' food vendors randomly selected; $\mathrm{KNL}_{3}$ is 'low class' food vendors randomly selected. WFD is weight of food delicacy bought $(\mathrm{g})$; $\mathrm{Fe}$ is amount of iron fillings in food delicacy bought (g); $\mathrm{ACFe}$ is rate of iron consumption in food delicacy $(\mathrm{mg} / \mathrm{g})$; NA is not applicable-samples were not purchased but obtained with permission.

\subsection{Fe Consumption}

Analysis of the results above revealed that there was no $\mathrm{Fe}$ accumulation and concentration from any of the $\mathrm{TZ}$ samples from any of the 'high class' $\left(\mathrm{TZL}_{2}\right)$ vendors. Furthermore, it is clear that a typical Dagomba family does not prepare kenkey to eat at home so there were no domestic samples for Kenkey. Hence, there were no $\mathrm{Fe}$ accumulation and no concentration from domestic $\left(\mathrm{KNL}_{1}\right)$ samples. In order to get a summary of the amount of Fe accumulation and the food consumed, we determined the average weight of food delicacies from all the food delicacies we bought (GHC) as well as the samples obtained from the households (Table 9). In this case for instance, the weight of all the Koko samples obtained from the homes were added and the average $(A W D=422.80 \mathrm{~g})$ found. Similarly, the average of the weight of $\mathrm{Fe}$ accumulation found in all the Koko samples obtained from 
the homes was calculated $(A F e=0.22 g g)$ and the corresponding average of the $\mathrm{Fe}$ concentration was determined $(A C I F=0.50 \mathrm{mmg} / \mathrm{g})$. The same procedure was used to calculate the averages for TZ, Banku and Kenkey (Table 9). Study of the results showed that the average weight of food delicacies (AWD) and average accumulation of iron fillings (AFe) varied directly with the cost of the food delicacies (TZ, Banku and Kenkey) but the average concentration of iron fillings (ACIF) varied indirectly with the cost of the food delicacies. For example, the AWD and $\mathrm{AFe}$ for the various commercial $\mathrm{TZ}$ samples increased from $510.50 \mathrm{~g}$ and $0.62 \mathrm{~g}$ lowest, respectively to $2581.90 \mathrm{~g}$ and $1.97 \mathrm{~g}$ highest respectively, corresponding to GHC1.00 and GHC5.00, respectively. However, the ACIF for the various commercial $\mathrm{TZ}$ samples decreased from $1.21 \mathrm{~g}$ highest at GHC1.00 to $0.76 \mathrm{~g}$ lowest at GHC5.00 (Table 9). Whereas the highest average domestic iron accumulation (AFe) came from $\mathrm{TZ}(\mathrm{DmTZ}=0.95 \mathrm{~g})$ with the lowest from Koko $(\mathrm{DmKK}=0.22 \mathrm{~g})$, the highest average commercial iron accumulation $(\mathrm{AFe})$ also came from $\mathrm{TZ}(\mathrm{TZ}=1.97 \mathrm{~g})$ but with the lowest from Kenkey $(\mathrm{KN}=0.55 \mathrm{~g})$. However, the highest average domestic iron concentration (ACIF) came from Banku $(\mathrm{DmBK}=1.36 \mathrm{~g})$ with the lowest also from Koko $(\mathrm{DmKK}=0.50 \mathrm{~g})$ and the highest average commercial iron concentration (ACIF) again came from Banku $(\mathrm{BK}=$ $1.52 \mathrm{~g})$ but with the lowest from $\mathrm{TZ}(\mathrm{TZ}=0.80 \mathrm{~g})$.

For further analysis, we divided consumers into three (3) categories depending on the cost of food delicacy purchased in order to determine the level of Fe accumulation and $\mathrm{Fe}$ concentration in the food delicacy consumed.

\subsubsection{Light Consumers}

These are people who consume between GHC1.00 and GHC2.00 worth of the various food delicacies. For this case, a light consumer of TZ will eat an average of $773.90 \mathrm{~g}$ of TZ which will accumulate a minimum of $0.62 \mathrm{~g} \mathrm{Fe}$ and a maximum of $1.11 \mathrm{~g} \mathrm{Fe}$ in the food delicacy (TZ) with a minimum concentration of $1.07 \mathrm{mg}$ iron fillings per gram food delicacy $(1.07 \mathrm{mg} / \mathrm{g})$ and a maximum of $1.21 \mathrm{mg} / \mathrm{g}$ in the consumer (assuming that all the TZ bought is eaten). In the case of banku, a light consumer will eat an average of $801.86 \mathrm{~g}$ of banku which will translate to a minimum of $0.46 \mathrm{~g}$ and a maximum of $1.46 \mathrm{~g}$ Fe accumulation in the food delicacy (banku) with a minimum of $0.83 \mathrm{mg} / \mathrm{g}$ and a maximum of $1.52 \mathrm{mg} / \mathrm{g} \mathrm{Fe}$ concentration in the consumer (assume all the banku is eaten). For kenkey, a light consumer will eat an average of $592.57 \mathrm{~g}$ of kenkey which will have a minimum of $0.55 \mathrm{~g}$ and a maximum of $1.05 \mathrm{~g} \mathrm{Fe}$ accumulation in the food delicacy with a minimum of $1.17 \mathrm{mg} / \mathrm{g}$ and a maximum of $1.43 \mathrm{mg} / \mathrm{g}$ Fe concentration in the consumer (assume all the food is eaten). Therefore, a light consumer will have less Fe concentration from $\mathrm{TZ}$ $(1.14 \mathrm{mg} / \mathrm{g})$ than kenkey $(1.30 \mathrm{mg} / \mathrm{g})$ and banku $(1.18 \mathrm{mg} / \mathrm{g})$. This indicates that for a light consumer, it is safer to eat commercial TZ (which has less Fe concentration) compared to commercial kenkey which is also safer compared to commercial banku.
Table 9. Summary of food consumption with concentration of Iron Fillings.

\begin{tabular}{|c|c|c|c|c|}
\hline $\begin{array}{l}\text { Food } \\
\text { Delicacy }\end{array}$ & $\begin{array}{l}\text { Amount } \\
\text { (GHC) }\end{array}$ & AWD (g) & $\operatorname{AFe}(g)$ & $\begin{array}{l}\text { ACIF } \\
(\mathrm{mg} / \mathrm{g}) \\
\end{array}$ \\
\hline \multirow{6}{*}{ Koko } & $\mathrm{DmKK}^{\mathrm{a}}$ & 422.80 & 0.22 & 0.50 \\
\hline & 0.5 & 0.00 & 0.00 & 0.00 \\
\hline & 1.0 & 0.00 & 0.00 & 0.00 \\
\hline & 1.5 & 0.00 & 0.00 & 0.00 \\
\hline & 2.0 & 0.00 & 0.00 & 0.00 \\
\hline & 3.0 & 0.00 & 0.00 & 0.00 \\
\hline \multirow{6}{*}{$\mathrm{TZ}^{\mathrm{b}}$} & DmTZ & 1035.64 & 0.95 & 0.90 \\
\hline & 1.00 & 510.50 & 0.62 & 1.21 \\
\hline & 2.00 & 1037.30 & 1.11 & 1.07 \\
\hline & 3.00 & 1510.15 & 1.36 & 0.90 \\
\hline & 4.00 & 2088.00 & 1.67 & 0.80 \\
\hline & 5.00 & 2581.90 & 1.97 & 0.76 \\
\hline \multirow{6}{*}{ Banku } & DmBK & 690.26 & 0.95 & 1.36 \\
\hline & 1.00 & 640.32 & 0.46 & 0.83 \\
\hline & 2.00 & 963.39 & 1.46 & 1.52 \\
\hline & 3.00 & 1278.40 & 1.56 & 1.23 \\
\hline & 4.00 & 1638.45 & 1.71 & 1.05 \\
\hline & 5.00 & 2124.34 & 1.81 & 0.85 \\
\hline \multirow{6}{*}{ Kenkey } & $\mathrm{DmKN}^{\mathrm{c}}$ & 0.00 & 0.00 & 0.00 \\
\hline & 1.00 & 457.94 & 0.55 & 1.17 \\
\hline & 2.00 & 727.20 & 1.05 & 1.43 \\
\hline & 3.00 & 1066.93 & 1.53 & 1.48 \\
\hline & 4.00 & 1339.50 & 1.69 & 1.31 \\
\hline & 5.00 & 1789.40 & 1.76 & 1.03 \\
\hline
\end{tabular}

${ }^{a}$ Domestic koko (porridge) consumers; ${ }^{b}$ there was no accumulation of $\mathrm{Fe}$ in the food delicacies and no concentration of $\mathrm{Fe}$ in the consumer from any of the TZ samples from the 'high class' $\left(\mathrm{TZL}_{2}\right)$ commercial vendors; 'Typical family in the metropolis does not eat kenkey to at home because kenkey is not a staple delicacy for the Dagomba people hence, no samples from homes (domestic); AWD is the average weight of food delicacies bought (GHC) from Table 8. AFe is the average iron fillings from the food delicacies bought from able 8 . ACIF is the average concentration of iron fillings likely to be consumed from able 8 .

\subsubsection{Average Consumers}

These are people who consume GHC3.00 worth of the various food delicacies. An average consumer of $\mathrm{TZ}$ will eat about $1510.15 \mathrm{~g}$ of $\mathrm{TZ}$ which will have about $1.36 \mathrm{~g} \mathrm{Fe}$ accumulation in the food delicacy (TZ) with $0.90 \mathrm{mg} / \mathrm{g} \mathrm{Fe}$ concentration in the consumer. For banku, an average consumer will eat an average of $1278.40 \mathrm{~g}$ of banku which will translate to about $1.56 \mathrm{~g}$ Fe accumulation in the food delicacy with about $1.23 \mathrm{mg} / \mathrm{g}$ Fe concentration in the system of the consumer. In the case of kenkey, an average consumer will eat an average of $1066.93 \mathrm{~g}$ of kenkey which will have about $1.53 \mathrm{~g}$ Fe accumulation in the food delicacy with $1.48 \mathrm{mg} / \mathrm{g} \mathrm{Fe}$ concentration in the body of the consumer. Clearly, a light consumer is worse consuming TZ $(1.14 \mathrm{mg} / \mathrm{g}$ vrs $0.90 \mathrm{mg} / \mathrm{g})$, better consuming banku $(1.18 \mathrm{mg} / \mathrm{g}$ vrs $1.23 \mathrm{mg} / \mathrm{g})$ and good consuming Kenkey $(1.30 \mathrm{mg} / \mathrm{g}$ vrs $1.48 \mathrm{mg} / \mathrm{g}$ ) than an average consumer.

\subsubsection{Heavy Consumers}

These are people who consume between GHC4.00 and GHC5.00 worth of the various food delicacies. A heavy TZ consumer will eat an average of $2334.95 \mathrm{~g}$ of $\mathrm{TZ}$ which will have a minimum of $1.67 \mathrm{~g}$ and a maximum of $1.79 \mathrm{~g} \mathrm{Fe}$ accumulation in the food delicacy with a minimum of $0.80 \mathrm{mg} / \mathrm{g}$ and a maximum of $1.52 \mathrm{mg} / \mathrm{g}$ Fe concentration in 
the body of the consumer. In the case of banku, a heavy consumer will eat an average of $801.86 \mathrm{~g}$ of banku which will translate to a minimum of $1.71 \mathrm{~g}$ and a maximum of $1.81 \mathrm{~g} \mathrm{Fe}$ accumulation with a minimum of $0.85 \mathrm{mg} / \mathrm{g}$ and a maximum of $1.05 \mathrm{mg} / \mathrm{g}$ Fe concentration in the consumer. For kenkey, a heavy consumer will eat an average of $592.57 \mathrm{~g}$ of kenkey which will have a minimum of $1.69 \mathrm{~g}$ and a maximum of $1.76 \mathrm{~g} \mathrm{Fe}$ accumulation with a minimum of $1.03 \mathrm{mg} / \mathrm{g}$ and a maximum of $1.31 \mathrm{mg} / \mathrm{g} \mathrm{Fe}$ concentration in the body.
Therefore, an average consumer is better consuming TZ $(0.90 \mathrm{mg} / \mathrm{g}$ vrs $1.52 \mathrm{mg} / \mathrm{g})$ than a heavy consumer but worse consuming banku $(1.23 \mathrm{mg} / \mathrm{g}$ vrs $1.05 \mathrm{mg} / \mathrm{g})$ and worse consuming kenkey $(1.48 \mathrm{mg} / \mathrm{g}$ vrs $1.31 \mathrm{mg} / \mathrm{g})$. These last two (2) trends (worse conditions) are understandable since the values of the average consumers are absolute at GHC3.00 whereas those of the heavy consumers are averages at GHC4.00 and GHC5.00.

Table 10. Meal Preferences and concentration of Iron Fillings.

\begin{tabular}{|c|c|c|c|c|c|c|c|}
\hline \multirow{2}{*}{ Category } & \multicolumn{3}{|l|}{ Preference } & \multicolumn{2}{|l|}{$\mathrm{Fe}(\mathrm{g})$} & \multicolumn{2}{|l|}{$\mathrm{ACFe}(\mathrm{mg} / \mathrm{g})$} \\
\hline & Breakfast & Lunch & Super & Meals debris & Total & Meals debris & Total \\
\hline \multirow{8}{*}{$\begin{array}{l}\text { Domestic } \\
\text { consumers }\end{array}$} & $\mathrm{TZ}_{1}$ & $\mathrm{TZ}_{1}$ & $\mathrm{TZ}_{1}$ & $0.95+0.95+0.95$ & 2.85 & $0.91+0.91+0.91$ & 2.73 \\
\hline & koko $_{1}$ & $\mathrm{TZ}_{1}$ & $\mathrm{TZ}_{1}$ & $0.22+0.95+0.95$ & 2.12 & $0.50+0.91+0.91$ & 2.32 \\
\hline & $\mathrm{TZ}_{1}$ & koko $_{1}$ & Banku $_{1}$ & $0.95+0+0.95$ & 1.90 & $0.91+0+1.36$ & 2.27 \\
\hline & $\mathrm{TZ}_{1}$ & $\mathrm{TZ}_{1}$ & Banku $_{1}$ & $0.95+0.95+0.95$ & 2.85 & $0.91+0.91+1.36$ & 3.18 \\
\hline & Banku $_{1}$ & Banku $_{1}$ & $\mathrm{Banku}_{1}$ & $0.95+0.95+0.95$ & 2.85 & $1.36+1.36+1.36$ & $4.08^{1 s t}$ \\
\hline & Banku $_{1}$ & $\mathrm{TZ}_{1}$ & Banku $_{1}$ & $0.95+0.95+0.95$ & 2.85 & $1.36+0.91+1.36$ & 3.62 \\
\hline & koko $_{1}$ & koko $_{1}$ & $\mathrm{TZ}_{1}$ & $0.22+0+0.95$ & 1.17 & $0.50+0+0.91$ & 1.41 \\
\hline & koko $_{1}$ & koko $_{1}$ & Banku $_{1}$ & $0.22+0+0.95$ & 1.17 & $0.50+0+1.36$ & 1.86 \\
\hline \multirow{8}{*}{$\begin{array}{l}\mathrm{L}_{2} \text { Commercial } \\
\text { consumers }\end{array}$} & $\mathrm{TZ}_{2}$ & $\mathrm{TZ}_{2}$ & $\mathrm{TZ}_{2}$ & $0+0+0$ & 0 & $0+0+0$ & $0^{\mathrm{a}}$ \\
\hline & $\mathrm{TZ}_{2}$ & koko $_{2}$ & Banku $_{2}$ & $0+0+1.41$ & 1.41 & $0+0+1.14$ & $1.14^{\mathrm{b}}$ \\
\hline & $\mathrm{Banku}_{2}$ & $\mathrm{TZ}_{2}$ & Banku $_{2}$ & $1.41+0+1.41$ & 2.82 & $1.14+0+1.14$ & $2.28^{\mathrm{c}}$ \\
\hline & $\mathrm{TZ}_{2}$ & $\mathrm{TZ}_{2}$ & Kenkey $_{2}$ & $0+0+1.30$ & 1.30 & $0+0+1.26$ & $1.26^{\mathrm{d}}$ \\
\hline & $\mathrm{TZ}_{2}$ & $\mathrm{Banku}_{2}$ & Kenkey $_{2}$ & $0+1.41+1.30$ & 2.71 & $0+1.14+1.26$ & 2.40 \\
\hline & Kenkey $_{2}$ & $\mathrm{Banku}_{2}$ & Banku $_{2}$ & $1.30+1.41+1.41$ & 4.12 & $1.26+1.14+1.14$ & 3.54 \\
\hline & Kenkey $_{2}$ & Kenkey $_{2}$ & $\mathrm{Banku}_{2}$ & $1.30+1.30+1.41$ & 4.01 & $1.26+1.26+1.14$ & $3.66^{\mathrm{e}}$ \\
\hline & Kenkey $_{2}$ & Kenkey $_{2}$ & Kenkey $_{2}$ & $1.30+1.30+1.30$ & 3.90 & $1.26+1.26+1.26$ & $3.78^{3 \mathrm{rd}}$ \\
\hline \multirow{19}{*}{$\begin{array}{l}\mathrm{L}_{3} \text { Commercial } \\
\text { consumers }\end{array}$} & koko $_{2}$ & Kenkey $_{2}$ & Kenkey $_{2}$ & $0+1.30+1.30$ & 2.60 & $0+1.26+1.26$ & $2.52^{\mathrm{f}}$ \\
\hline & $\mathrm{TZ}_{3}$ & $\mathrm{TZ}_{3}$ & $\mathrm{TZ}_{3}$ & $1.34+1.34+1.34$ & 4.02 & $0.95+0.95+0.95$ & 2.85 \\
\hline & $\mathrm{koko}_{3}$ & $\mathrm{TZ}_{3}$ & $\mathrm{TZ}_{3}$ & $0+1.34+1.34$ & 2.68 & $0+0.95+0.95$ & 1.90 \\
\hline & $\mathrm{TZ}_{3}$ & $\mathrm{kokO}_{3}$ & $\mathrm{Banku}_{3}$ & $1.34+0+1.38$ & 2.72 & $0.95+0.95+1.04$ & 1.99 \\
\hline & $\mathrm{TZ}_{3}$ & $\mathrm{TZ}_{3}$ & $\mathrm{Banku}_{3}$ & $1.34+1.34+1.38$ & 4.06 & $0.95+0.95+1.04$ & 2.94 \\
\hline & $\mathrm{Banku}_{3}$ & Banku $_{3}$ & $\mathrm{Banku}_{3}$ & $1.38+1.38+1.38$ & 4.14 & $1.04+1.04+1.04$ & 3.12 \\
\hline & $\mathrm{Banku}_{3}$ & $\mathrm{TZ}_{3}$ & $\mathrm{Banku}_{3}$ & $1.38+1.34+1.38$ & 4.10 & $1.04+0.95+1.04$ & $3.03^{\mathrm{g}}$ \\
\hline & $\mathrm{koko}_{3}$ & $\mathrm{koko}_{3}$ & $\mathrm{TZ}_{3}$ & $0+0+1.34$ & 1.34 & $0+0+0.95$ & 0.95 \\
\hline & $\mathrm{kokO}_{3}$ & $\mathrm{kokO}_{3}$ & $\mathrm{Banku}_{3}$ & $0+0+1.38$ & 1.38 & $0+0+1.04$ & 1.04 \\
\hline & $\mathrm{TZ}_{3}$ & $\mathrm{TZ}_{3}$ & Kenkey $_{3}$ & $1.34+1.34+1.39$ & 4.07 & $0.95+0.95+1.34$ & 3.24 \\
\hline & $\mathrm{TZ}_{3}$ & $\mathrm{Banku}_{3}$ & Kenkey $_{3}$ & $1.34+1.38+1.39$ & 4.11 & $0.95+1.04+1.34$ & 3.33 \\
\hline & $\mathrm{kokO}_{3}$ & $\mathrm{Banku}_{3}$ & $\mathrm{Banku}_{3}$ & $0+1.38+1.38$ & 2.76 & $0+1.04+1.04$ & 2.08 \\
\hline & $\mathrm{koko}_{3}$ & $\mathrm{kokO}_{3}$ & Kenkey $_{3}$ & $0+0+1.39$ & 1.39 & $0+0+1.34$ & 1.34 \\
\hline & Kenkey $_{3}$ & $\mathrm{Banku}_{3}$ & $\mathrm{Banku}_{3}$ & $1.39+1.38+1.38$ & 4.15 & $1.34+1.04+1.04$ & $3.42^{\mathrm{h}}$ \\
\hline & Kenkey3 & Kenkey3 & Banku3 & $1.39+1.39+1.38$ & 4.16 & $1.34+1.34+1.04$ & $3.72^{\mathrm{i}}$ \\
\hline & Kenkey $_{3}$ & Kenkey $_{3}$ & Kenkey $_{3}$ & $1.39+1.39+1.39$ & 4.17 & $1.34+1.34+1.34$ & $4.02^{2 n d}$ \\
\hline & $\mathrm{koko}_{3}$ & Kenkey $_{3}$ & Kenkey $_{3}$ & $0+1.39+1.39$ & 2.78 & $0+1.34+1.34$ & 2.68 \\
\hline & Kenkey $_{3}$ & $\mathrm{TZ}_{3}$ & Kenkey $_{3}$ & $1.39+1.34+1.39$ & 4.12 & $1.34+0.95+1.34$ & 3.63 \\
\hline & $\mathrm{kokO}_{3}$ & $\mathrm{TZ}_{3}$ & Kenkey $_{3}$ & $0+1.34+1.39$ & 2.73 & $0+0.95+1.34$ & 2.29 \\
\hline
\end{tabular}

${ }^{\mathrm{a}} \mathrm{TZ}_{2}+\mathrm{TZ}_{2}+\mathrm{TZ}_{2}=\mathrm{Koko}_{2}+\mathrm{Koko}_{2}+\mathrm{TZ}_{2}=\mathrm{Koko}_{2}+\mathrm{TZ}_{2}+\mathrm{TZ}_{2}=0 \mathrm{mg} / \mathrm{g} ;{ }^{\mathrm{b}} \mathrm{TZ}_{2}+\mathrm{Koko}_{2}+\mathrm{Banku}_{2}=\mathrm{TZ}_{2}+\mathrm{TZ}_{2}+\mathrm{Banku}_{2}=\mathrm{Koko}_{2}+\mathrm{Koko}_{2}+\mathrm{Banku}_{2}=1.14$ $\mathrm{mg} / \mathrm{g} ;{ }^{\mathrm{c}} \mathrm{Banku}_{2}+\mathrm{TZ}_{2}+\mathrm{Banku}_{2}=\mathrm{Koko}_{2}+\mathrm{Banku}_{2}+\mathrm{Banku}_{2}=2.28 \mathrm{mg} / \mathrm{g} ;{ }^{\mathrm{d}} \mathrm{TZ}_{2}+\mathrm{TZ}_{2}+\mathrm{Kenkey}_{2}=\mathrm{Koko}_{2}+\mathrm{Koko}_{2}+\mathrm{Kenkey}_{2}=\mathrm{Koko}_{2}+\mathrm{TZ}_{2}+\mathrm{Kenkey}_{2}=1.26$ $\mathrm{mg} / \mathrm{g} ;{ }^{\mathrm{e}} \mathrm{Kenky}_{2}+\mathrm{Kenkey}_{2}+\mathrm{Banku}_{2}=\mathrm{Kenky}_{2}+\mathrm{Banku}_{2}+\mathrm{Kenkey}_{2}=3.66 \mathrm{mg} / \mathrm{g}$; ${ }^{\mathrm{f}} \mathrm{Koko}_{2}+\mathrm{Kenkey}_{2}+\mathrm{Kenkey}_{2}=\mathrm{Kenkey}_{2}+\mathrm{TZ}_{2}+\mathrm{Kenkey}_{2}=2.52 \mathrm{mg} / \mathrm{g}$; ${ }^{\mathrm{g}} \mathrm{Banku}_{3}+\mathrm{TZ}_{3}+\mathrm{Banku}_{3}=\mathrm{TZ}_{3}+\mathrm{Banku}_{3}+\mathrm{Banku}_{3}=3.03 \mathrm{mg} / \mathrm{g} ;{ }^{\mathrm{h}} \mathrm{Kenkey}_{3}+\mathrm{Banku}_{3}+\mathrm{Banku}_{3}=\mathrm{Banku}_{2}+\mathrm{Banku}_{2}+\mathrm{Banku}_{2}=3.42 \mathrm{mg} / \mathrm{g} ;{ }^{\mathrm{i}} \mathrm{Kenky}_{3}+\mathrm{Kenkey}_{3}+$ $\mathrm{Banku}_{3}=\mathrm{Kenky}_{3}+\mathrm{Banku}_{3}+\mathrm{Kenkey}_{3}=3.72 \mathrm{mg} / \mathrm{g}$.

\subsection{Meal Preference}

The typical Dagomba man eats porridge or $\mathrm{TZ}$ for breakfast, TZ for lunch and TZ for supper. These meals were hitherto prepared at home for consumption. However, the
Tamale Metropolis is no longer a typical Dagomba community due to modernization. There has been avalanche of food vendors leading to tremendous variety of meal preferences. By meal preference, we mean the type of food delicacy an individual eats for breakfast, lunch or supper. 
Consequently, we studied how the accumulation of $\mathrm{Fe}$ in the food delicacies and concentration of $\mathrm{Fe}$ in the alimentary canal of consumers can be influenced by meal preferences (Table 10) depending on the various categories of food delicacies (Tables 5-8). A meal with a subscript (1) refers to meals prepared for domestic consumption. For example, 'Koko ${ }_{1}$ ' represents porridge prepared for domestic consumption; ' $\mathrm{TZ}_{1}$ ' is $\mathrm{TZ}$ meal prepared for domestic consumption; ' $B a n k u_{1}$ ' is banku meal prepared for domestic consumption and 'Kenkey,' is kenkey meal prepared for domestic consumption. Meals with subscript (2) refer to meals prepared for commercial consumption from 'high class' food vendors with massive patronage. For instance, ' $\mathrm{KokO}_{2}$ ' represents porridge sold by 'high class' commercial vendors; ' $\mathrm{TZ} Z_{2}$ ' is $\mathrm{TZ}$ meal sold by 'high class' commercial vendors; 'Banku,' is banku meal sold by 'high class' commercial vendors and 'Kenkey,' is kenkey meal sold by 'high class' commercial vendors. Meals with subscript (3) refer to meals prepared for commercial consumption from 'low class' food vendors who have low patronage. ' $\mathrm{Koko}_{3}$ ' for example, represents porridge sold by 'low class' commercial vendors; ' $\mathrm{TZ}_{3}$ ' is $\mathrm{TZ}$ meal sold by 'low class' commercial vendors; 'Banku' ' is banku meal sold by 'low class' commercial vendors and 'Kenkey ${ }_{3}$ ' is kenkey meal sold by 'low class' commercial vendors.

Recall that there was no trace of iron fillings (Fe) from all the commercial porridge samples (Tale 5). There was also no $\mathrm{Fe}$ accumulation from the food samples purchased from any of the 'high class' commercial $\mathrm{TZ}$ vendors $\left(\mathrm{TZ}_{2}\right.$ Table 6$)$. For example, a day's meals prepared for domestic consumption as breakfast, lunch and super $\left(\right.$ Koko $_{1}+\mathrm{TZ}_{1}+$ Banku $_{1}$ respectively) will have about $2.85 \mathrm{~g}$ total $\mathrm{Fe}$ accumulation in the meals but the total $\mathrm{Fe}$ concentration in the body for the day will be $2.73 \mathrm{mg} / \mathrm{g}$ after consuming all the meals (Table 10). What this means is that the meal for the day will accumulate $0.95 \mathrm{~g}$ Fe from breakfast, $0.95 \mathrm{~g}$ Fe from lunch, and $0.95 \mathrm{~g} \mathrm{Fe}$ from supper leading to a total $\mathrm{Fe}$ accumulation of $2.85 \mathrm{~g}$. However, the body which consumes the meal will absorb $0.91 \mathrm{mg}$ of Fe per $\mathrm{g}$ of meal from breakfast, $0.91 \mathrm{mg} / \mathrm{g}$ $\mathrm{Fe}$ from lunch, and $0.91 \mathrm{mg} / \mathrm{g}$ Fe from supper leading to $2.73 \mathrm{mg} / \mathrm{g}$ total $\mathrm{Fe}$ concentration in the body. Fe accumulation is the total amount of iron fillings $(\mathrm{g})$ found in the meal but $\mathrm{Fe}$ concentration is the total amount of iron fillings (mg) divided by the amount of meal (g) likely to be consumed by an individual. Therefore, $\mathrm{Fe}$ concentration is actually the amount of iron fillings which will be concentrated in the human system assuming that all the food containing the Fe is consumed. Our focus henceforth will be on Fe concentration.

The results show that the highest Fe concentration is $4.08 \mathrm{mg} / \mathrm{g}$ corresponding to banku prepared for domestic consumption as breakfast, lunch and super $\left(\mathrm{Banku}_{1}+\mathrm{Banku}_{1}\right.$ $\left.+\mathrm{Banku}_{1}\right)$ indicating that the worst meal preference is to eat banku prepared at home for breakfast, eat banku again at home for lunch and then eat Banku at home again for supper. The next highest Fe concentration is $4.02 \mathrm{mg} / \mathrm{g}$ corresponding to buying meals from 'low class' commercial kenkey vendors for consumption as breakfast, lunch and super $\left(\right.$ Kenkey $_{3}+$
Kenkey $_{3}+$ Kenkey $_{3}$ ) suggesting that the worse meal preference is to eat Kenkey sold by 'low class' commercial Kenkey vendors for breakfast, eat Kenkey sold by 'low class' commercial Kenkey vendors again for lunch and then eat Kenkey sold by 'low class' commercial Kenkey vendors again for supper. The third $\left(3^{\text {rd }}\right)$ highest Fe concentration is $3.78 \mathrm{mg} / \mathrm{g}$ corresponding to buying meals from 'high class' commercial kenkey vendors for consumption as breakfast, lunch and super $\left(\right.$ Kenkey $_{2}+$ Kenkey $_{2}+$ Kenkey $\left._{2}\right)$ suggesting that another worse meal preference is to eat kenkey sold by 'high class' commercial kenkey vendors for breakfast, eat kenkey sold by 'high class' commercial kenkey vendors again for lunch and then eat kenkey sold by 'high class' commercial kenkey vendors again for supper.

However, the best meal preferences are three (3); they have zero or no Fe concentration: One of the best meal preferences is to eat $\mathrm{TZ}$ sold by 'high class' commercial $\mathrm{TZ}$ vendors $\left(\mathrm{TZ}_{2}\right)$ for breakfast, for lunch and again for supper $\left.\left(\mathrm{TZ}_{2}+\mathrm{TZ}_{2}+\mathrm{TZ}_{2}\right) ; 2\right)$. Another best meal preference is to take porridge (Koko) sold by 'high class' commercial porridge vendors $\left(\mathrm{Koko}_{2}\right)$ for breakfast, for lunch and again for supper $\left(\mathrm{Koko}_{2}+\mathrm{Koko}_{2}+\mathrm{Koko}_{2}\right)$. The final best meal preference is to eat combination of $\mathrm{TZ}$ sold by 'high class' commercial $\mathrm{TZ}$ vendors $\left(\mathrm{TZ}_{2}\right)$ and porridge (Koko) sold by 'high class' commercial porridge vendors $\left(\mathrm{Koko}_{2}\right)$ for breakfast, for lunch and for supper $\left(\mathrm{TZ}_{2}+\mathrm{TZ}_{2}+\mathrm{Koko}_{2} ; \mathrm{TZ}_{2}\right.$ $+\mathrm{Koko}_{2}+\mathrm{Koko}_{2} ; \mathrm{TZ}_{2}+\mathrm{Koko}_{2}+\mathrm{TZ}_{2} ; \mathrm{Koko}_{2}+\mathrm{Koko}_{2}+$ $\mathrm{TZ}_{2} ; \mathrm{Koko}_{2}+\mathrm{TZ}_{2}+\mathrm{TZ}_{2}$ and $\mathrm{Koko}_{2}+\mathrm{TZ}_{2}+\mathrm{Koko}_{2}$ ). Meanwhile, the better meal preference has $0.95 \mathrm{mg} / \mathrm{g} \mathrm{Fe}$ concentration which is to take porridge sold by 'low class' commercial porridge vendors $\left(\mathrm{KokO}_{3}\right.$ which has zero or no $\mathrm{Fe}$ concentration) for breakfast and again for lunch but eat $\mathrm{TZ}$ sold by 'low class' commercial $\mathrm{TZ}$ vendors $\left(\mathrm{TZ}_{3}\right.$ which has $0.95 \mathrm{mg} / \mathrm{g} \mathrm{Fe}$ concentration) for supper $\left(\mathrm{Koko}_{3}+\mathrm{Koko}_{3}+\right.$ $\mathrm{TZ}_{3}$ ). Moreover, the good meal preference has $1.04 \mathrm{mg} / \mathrm{g} \mathrm{Fe}$ concentration which is to take porridge sold by 'low class' commercial porridge vendors for breakfast and again for lunch but eat banku sold by 'low class' commercial banku vendors $\left(\mathrm{Banku}_{3}\right.$ with $1.04 \mathrm{mg} / \mathrm{g}$ Fe concentration) for supper $\left(\mathrm{Koko}_{3}+\mathrm{Koko}_{3}+\mathrm{Banku}_{3}\right)$.

\section{Conclusions}

We investigated the amount of iron fillings produced as debris in corn flour during milling and assessed the accumulation of iron fillings in food delicacies and the concentration of iron fillings in human system using a permanent magnet. Based on the study, we conclude that:

1. Flour milled with new pair of plates is likely to contain 1.5 folds the amount of Fe than flour milled with old pair of plates.

2. Wet milling is the safer choice for producing flour than dry milling.

3. Consuming domestic koko will lead to absorbing $\approx$ $1.20 \mathrm{mg} / \mathrm{g}$ iron fillings in the body.

4. There was no Fe accumulation and no Fe concentration from any of the 'high class' commercial TZ vendors; 
they produced the best choice for $\mathrm{TZ}$ consumption but the 'low class' commercial $\mathrm{TZ}$ vendors produced the worse choice for $\mathrm{TZ}$ consumption.

5. For a light consumer, it is safer to eat $\mathrm{TZ}$ (less iron fillings) compared to Banku which is also safer compared to kenkey.

6. The worst meal preference is to eat 3-square (breakfast, lunch and supper) meals of banku prepared at home.

7. The best meal preferences are: either eat 3-square meals of TZ from 'high class' commercial TZ vendors; or take 3-square meals of porridge (Koko) from 'high class' commercial porridge vendors; or eat 3-square meals combination of TZ from 'high class' commercial TZ vendors and porridge (Koko) from 'high class' commercial porridge vendors.

\section{Contribution of Researchers}

Abdul-Rauf Ibrahim-Developed the concept and structure of the research work and also analysed the results of the experiments.

Abdul-Mumin Abdulai-Developed the introduction towards the SDGs, economic analysis of food vendors and patterns of consumption behaviours among different consumers of milled corn flour and designed the questionnaires used for the research work.

Tarlutu Ibrahim-Designed and produced the magnetic stirrer used to attract the iron fillings and performed the experiments.

Sulemana Yahaya-Identified and selected milling centres and the various food vendors.

Alhassan Fadila- collected the flour samples from the milling centers and the houses.

Alhassan Yakubu- collected the food samples from the food vendors and the houses.

\section{Acknowledgements}

This work is supported by the Ghana government book and research allowance.

\section{References}

[1] Hollinger, F., \& Staatz, J. M., (2015). Agricultural growth in West Africa: Market and policy drivers. FAO and AfDB, https://doi.org/10.1073/pnas.1108924108

[2] Amugsi, D. A., Lartey, A., Kimani, E., \& Mberu, B. U. (2016). Women's participation in household decision-making and higher dietary diversity: Findings from nationally representative data from Ghana. Journal of Health, Population and Nutrition, 35 (1), 16.

[3] MoFA, (2001). Agriculture in Ghana: facts and figures issued by statistics, research and information directorate, 28 .

[4] Atikpo, M. A. O., Abbey, L. D., Glover-Amengor, M., Lawer, L., Ayin, J., \& Toppe, J. (2012). Micronutrient enrichment of meals fed to pupils using highly nutritious and lowcost underutilized fish under the school feeding programme in Ghana, Rome.

[5] Gwirtz, J. A., \& Garcia-Casal, M. N., (2014). Processing maize flour and corn meal food products. Annals of the New York Academy of Sciences, 1312 (1), 66-75.

[6] Oduro-Yeboah, C., Amoa-Awua, W., Saalia, F. K., Bennett, B., Annan, T., Sakyi-Dawson, E., et al., (2018). Application OF a value chain approach to understanding, African Journal of Food, Agriculture, Nutrition and Development, 18 (2), 13406-13419.

[7] Adeti, P. J. (2015). Assessment of heavy metals introduced into food through milling process: Health implications, Dissertation, University of Ghana, http://ugspace.ug.edu.gh/handle/123456789/23639, Date: 2015-07.

[8] Dallatu, Y. A., Shallangwa, G. A., \& Ibrahim, W. A., (2016). Effect of milling on the level of heavy metal contamination of some Nigerian foodstuffs. International Journal of Chemical, Material and Environmental Research, 3 (2), 29-34.

[9] Joseph K. Adu, Dzakadzie Fafanyo, Emmanuel Orman, Isaac Ayensu, Cedric D. K. Amengor, Samuel Kwofie, (2020). Assessing metal contaminants in milled maize products available on the Ghanaian market with Atomic Absorption Spectrometry and Instrumental Neutron Activation Analyser techniques, Food Control 109, 106912.

[10] Kwofie, S., \& Chandler, H., (2011). Potential health effects of locally-manufactured cornmill grinding plates. Journal of Science and Technology, 26 (2).

[11] Normanyo, E. K, Esiam K., Amankwa-Poku I. A, \& Adetunde E., (2010). Redesign of a Grinding Mill for the Minimization of Iron Filings Production, Researcher, 2 (7), 60-75.

[12] Edem, C. A. and Dosunmu, M. I. (2012). Determination of Heavy Metals in Cobs of Maize (Zea Mays) from Calabar South Local Government Area of Cross River State Nigeria, IJRRAS, 13: 346-348.

[13] Anthony, B. O.; C. G. Chukwu, O. O. Lawal \& T. S. Osinaike, (2013). Some Nigerian Traditional Food Milling Techniques and Cookware Increases Concentrations of Some Heavy Metals in Milled Food. IOSR Journal of Pharmacy, 3: 6-13.

[14] Sule, O. S. and Odugbose, D. B., (2014). Assessment of Dry and Wet Milling using Fabricated Burr Mill. Food Science and Quality Management, 31: 1-12.

[15] WHO, (1973). Technical report series, trace elements in human nutrition, Report of WHO Expert Committee, No. 532, Geneva.

[16] Francis, J., (2009). The Effects of Iron on Your Heart Health, Available http://www.naturalhealthweb.com/articles/francis3.html. Accessed: June 16.

[17] Kwofi, S. and Chandler, H. D., (2006). Potential Health Effects of Locally Manufactured Corn-Mill Grinding Plates, Journal of Science and Technology, 26 (2): 138-147.

[18] Andrews, A., \& Kwofie, S. (2010). Corrosion of cast iron mill plates in wet grinding. Leonardo Electronic Journal of Practices and Technologies, 9 (17), 97-108.

[19] Hulthen, L., (2003). 'Iron Deficiency and Cognition' Scandinavian Journal of Nutrition, 47 (3): 152-156. 
[20] Hillan, J., Bombproof, L. B., (2006). Facts about Iron Available at http://edis.ifas.ufl.edu. Accessed: November 10, 2008.

[21] DPC Education Series, (2008). The Power of Iron: Its Critical Role in Kidney Disease, Available at http://www.dialysispatients.org. Accessed: March 10, 2009.

[22] Bello, I.; O. Oke \& A. O. Abdul Raheem, (2007). Levels of Calcium, Lead and Zinc Introduced as Contaminants into Food Stuff during Processing. Science Focus, 12 (2): 1-5.

[23] Yahaya, D. B.; Aremu D. A. \& Abdullahi I., (2012). Investigation of Metal Contaminants in Locally Grinded Foods (Beans and Tomatoes), JESTAS, 3 (1): 339-345.

[24] Reilly, C., (2002). Metal analysis of food. Metal contamination of food: Its significance for food quality and human health. $3^{\text {rd }}$ ed. Blackwell Science Ltd, 23-39.
[25] Wuana, R. A., \& Okieimen, F. E., (2014). Heavy Metal Contamination of Water and Soil: Analysis, Assessment, and Remediation Strategies 1-50.

[26] Nerín, C., Aznar, M., \& Carrizo, D., (2016). Food contamination during food process. Trends in Food Science \& Technology, 48, 63-68.

[27] Rai, P. K., Lee, S. S., Zhang, M., Tsang, Y. F., \& Kim, K. H., (2019). Heavy metals in food crops: Health risks, fate, mechanisms, and management. Environment International, 125 (January), 365-385.

[28] UNDP, 2021.

https://www.undp.org/content/undp/en/home/sustainabledevelopment-goals.html 